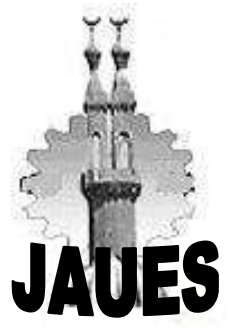

Journal of Al-Azhar University Engineering Sector

Vol.16, No. 61, October, 2021, 1515-1534

\title{
دور التخطيط العمراني في مجابهة مخاطر غرق الدلتا جراء ظاهرة الإحتباس الحراري
}

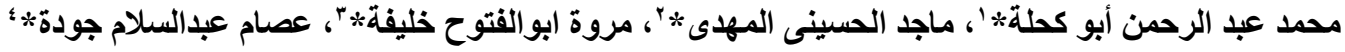

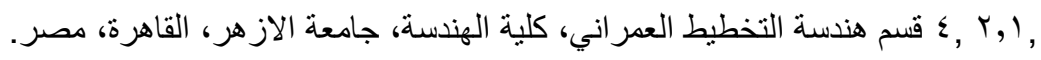 \\ r, قسم هندسة التخطيط العمر اني، كلية الهندسة، جامعة عين شمس، القاهرة، مصر. \\ البريد الاليكتروني للباحث الرئيسى: E-mail Maabukahla@gmail.com
}

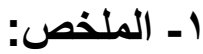

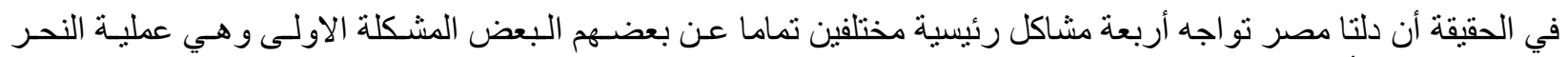

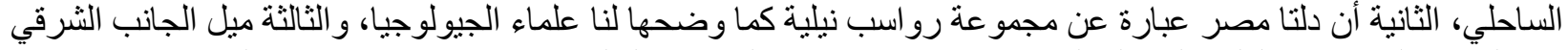

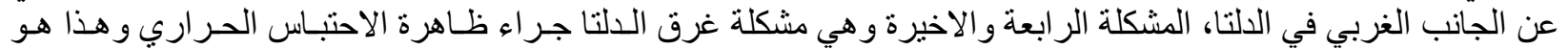

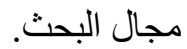

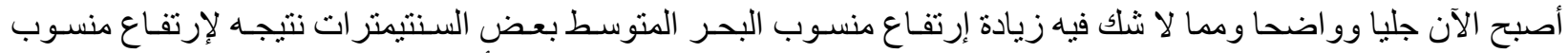

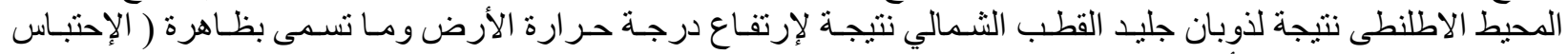

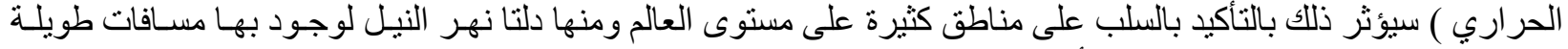

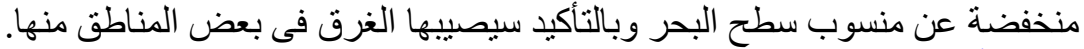

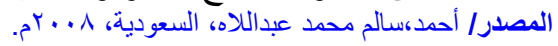

و عليه فقط أوضحت ال IPCC الهيئة الحكومية الدولية المعنية بتغيير المناخ في تقرير ها النهائي إرتفاع منسوب البحر المتوسط

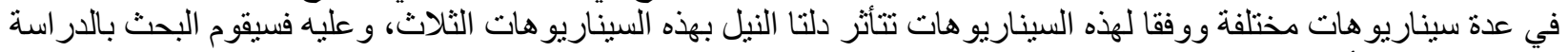

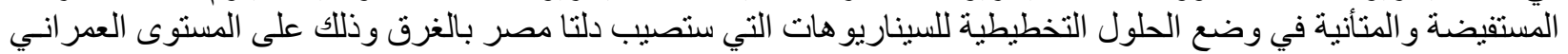
و الزر اعى و السياحي و الاجتماعي و الاقتصادي باستخدام إمكانيـات آليـات التنميـة النظيفة

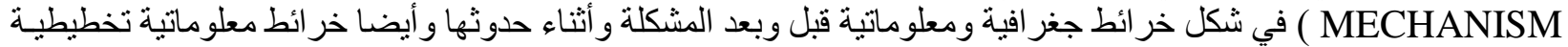

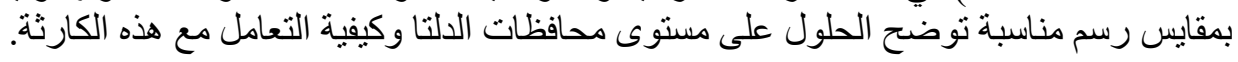

وسيتم إستخدام الأساليب التقنية و التكنولوجية الحديثة في إظهار المناطق المهددة بالغرق ووضع الحلول التخطيطية المدكنة لها

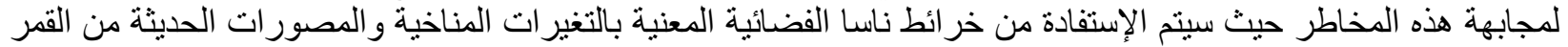

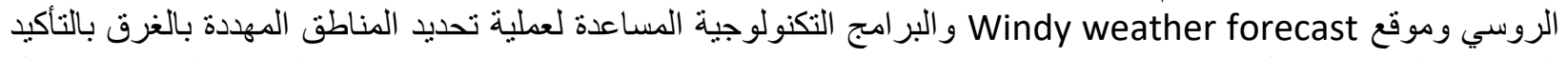

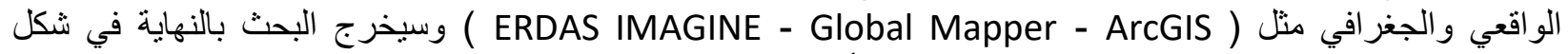
توصيات وخر وائط معلوماتية مكانية يمكن تنفيذها على أرض الواقع اقع، وسيتم ذكر الجهات التنفيذية لهذه الخرائط فى نهاية البحث مدرجة ضمن التوصيات و المقترحات. 


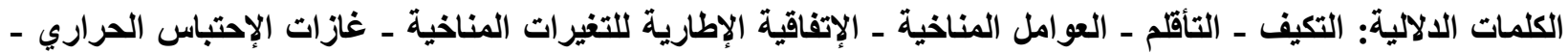

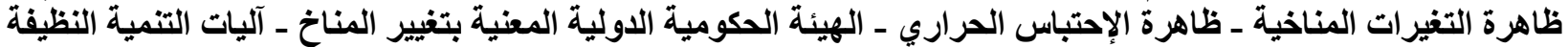

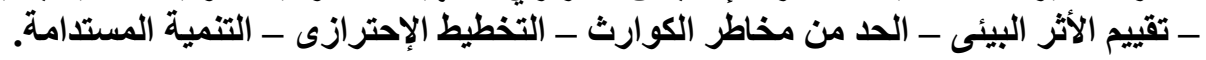

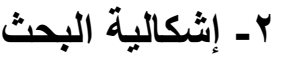

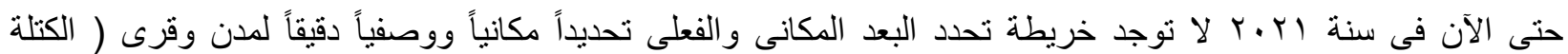

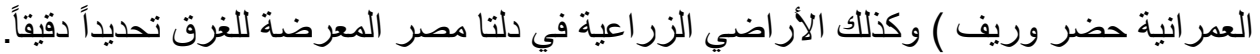

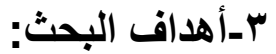

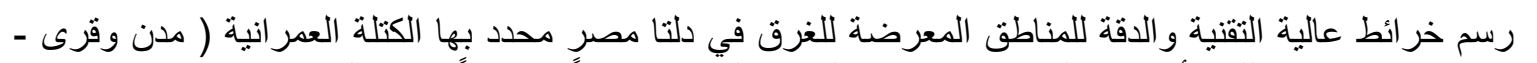
حضر وريف ) وكذللك الأر اضي الزر اعية و شبكة الطرق القائمة، مكانياً ووصفياً حتى الآن.

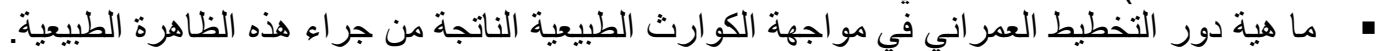

ع ـالمقدمة:

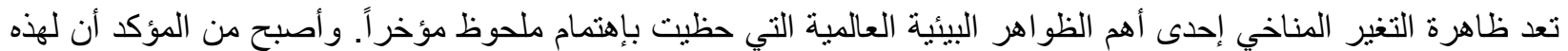

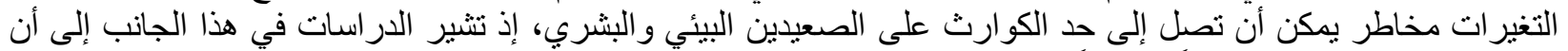

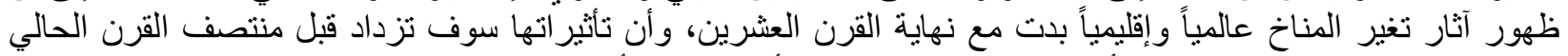

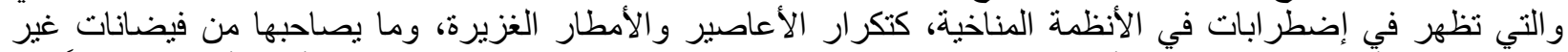

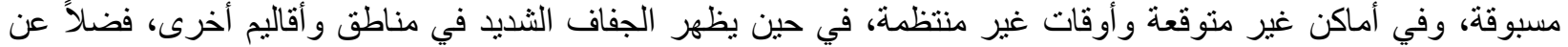

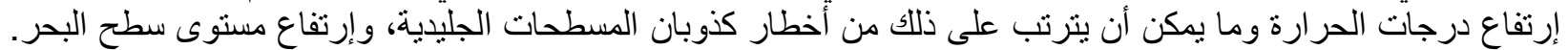

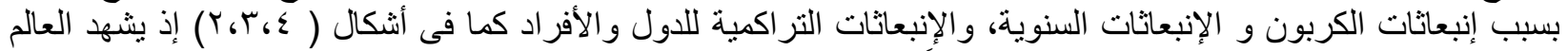

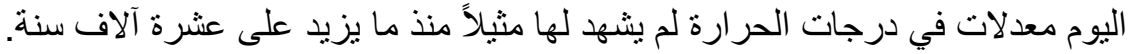

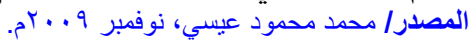

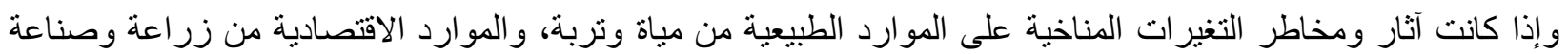

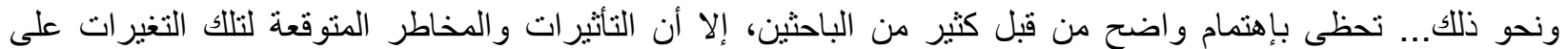

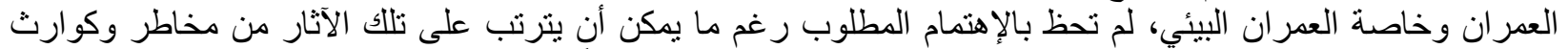

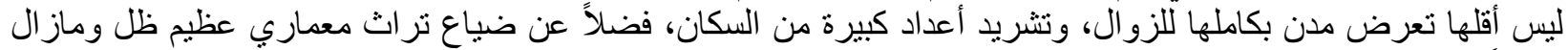

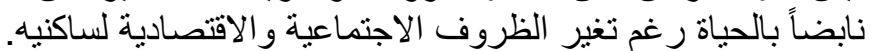

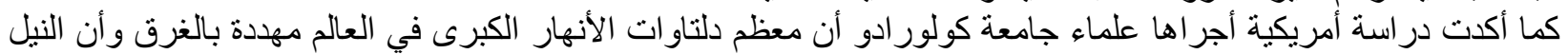

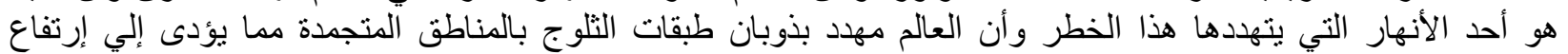

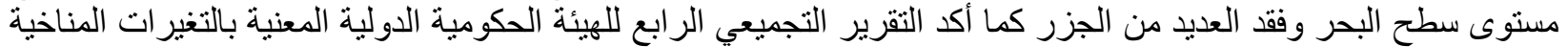

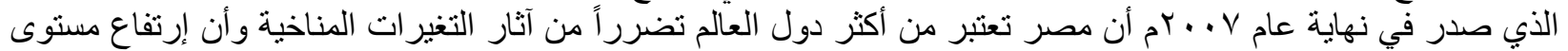

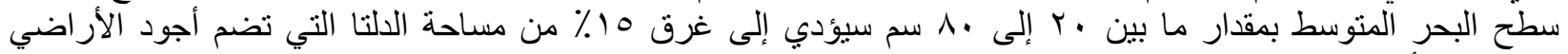

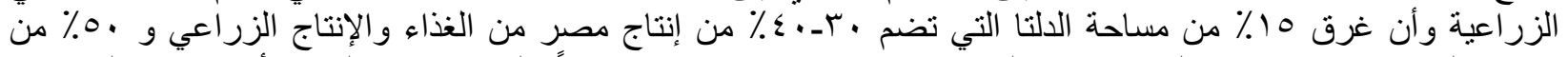

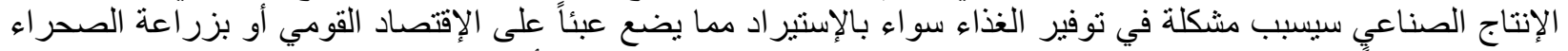

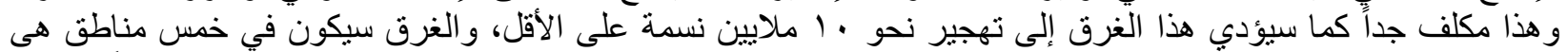

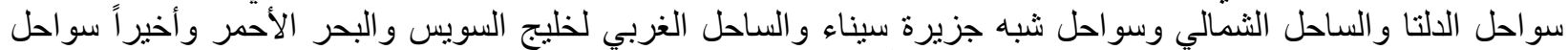

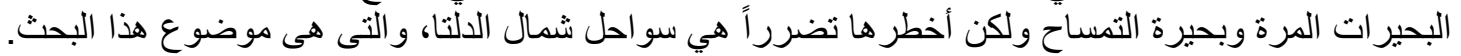

\section{هـ الغازات الافيئة ) - GHG emissions - Greenhouse gases ( GHG}

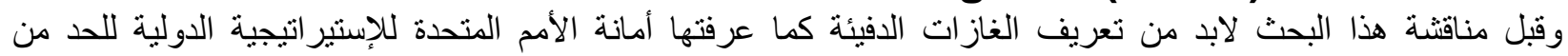

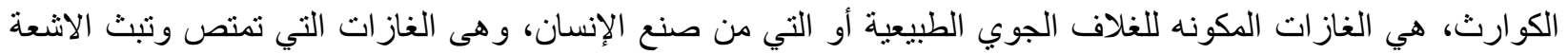

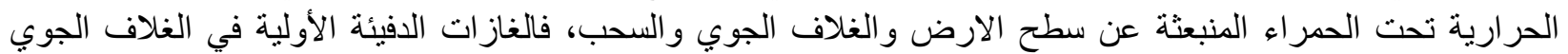

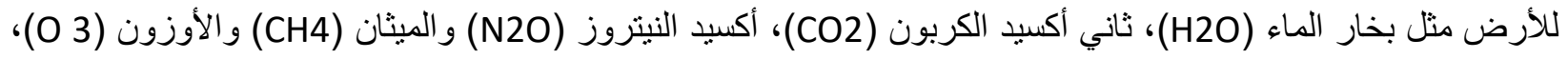

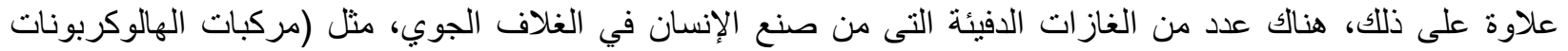


و الأثير المحتوية على الكلور والبروم سداسي فلوريد الكبريت، الهيدروكربونات الفلورية) كما هو واضح فى شكل ( ( ).

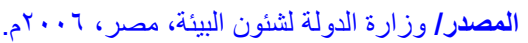

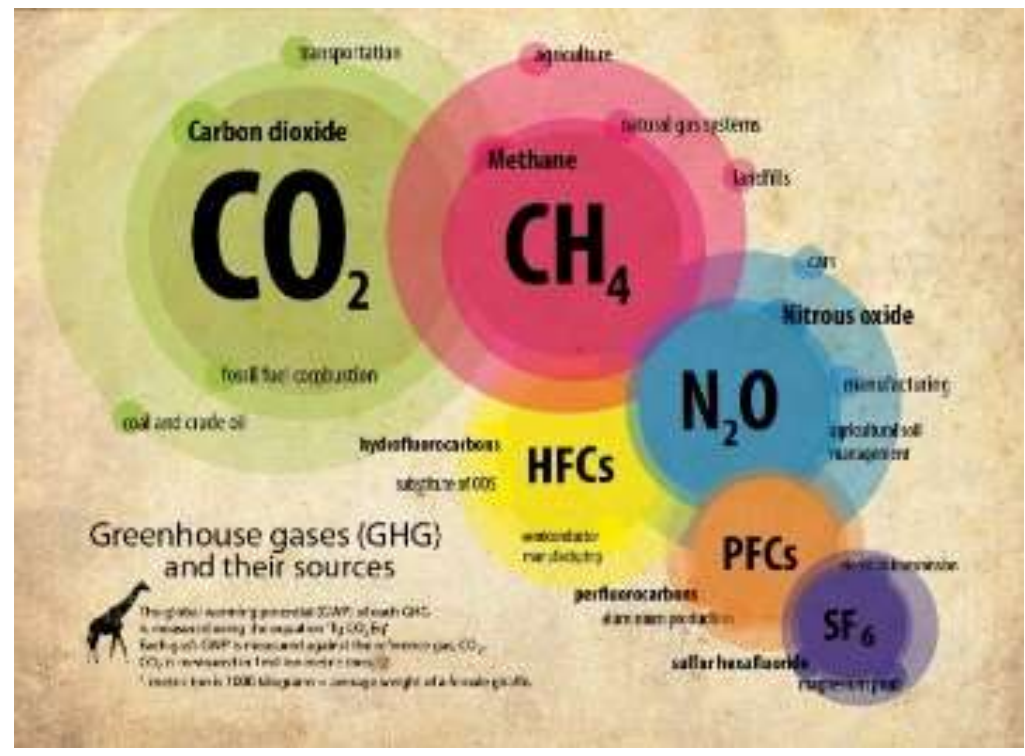

شكل ( 1 ) ) رسم توضيحى لمكونات الغازات الدفيئة

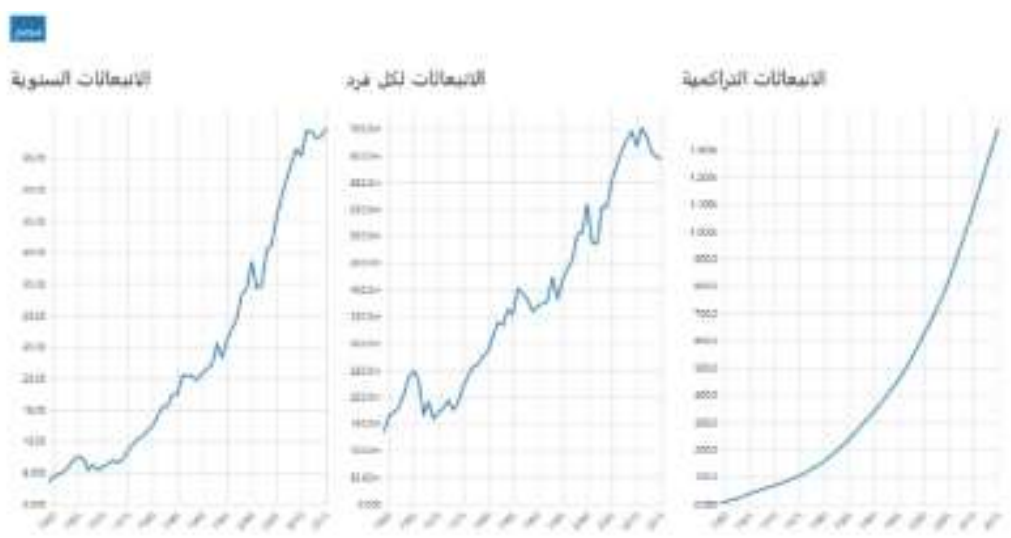

شكل ( r ) رسم بيانى يوضح إنبعاثات الكربون بمصر متضمنة الإنبعاثات السنوية، والإنبعاثات التراكمية بملايين الأطنان، والإنبعاثات لكل فرد بالطن. https://www.populationpyramid.net/carbon-emissions المصدر / تحليلات الباحث (r.r من موقع 


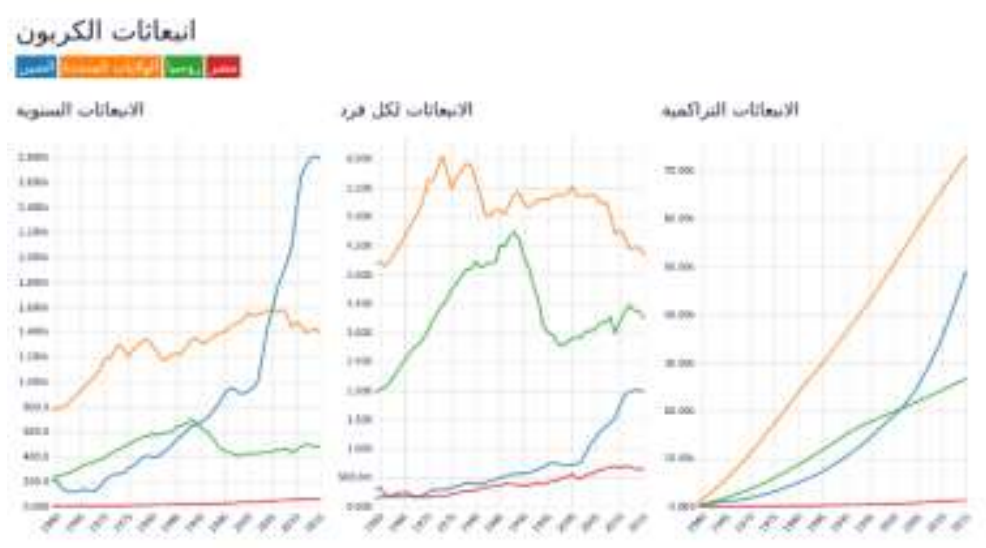

Bepdationpramidat

شكل ( ب ) رسم بيانى يوضح إنبعاثات الكربون لكل من الدول الكبرى الرئيسية المتسبية فى ظاهرة الإحتباس الحرارى ومقارنة إنبعاثات مصر

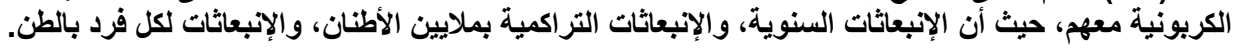

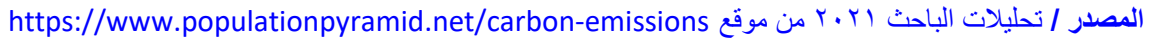

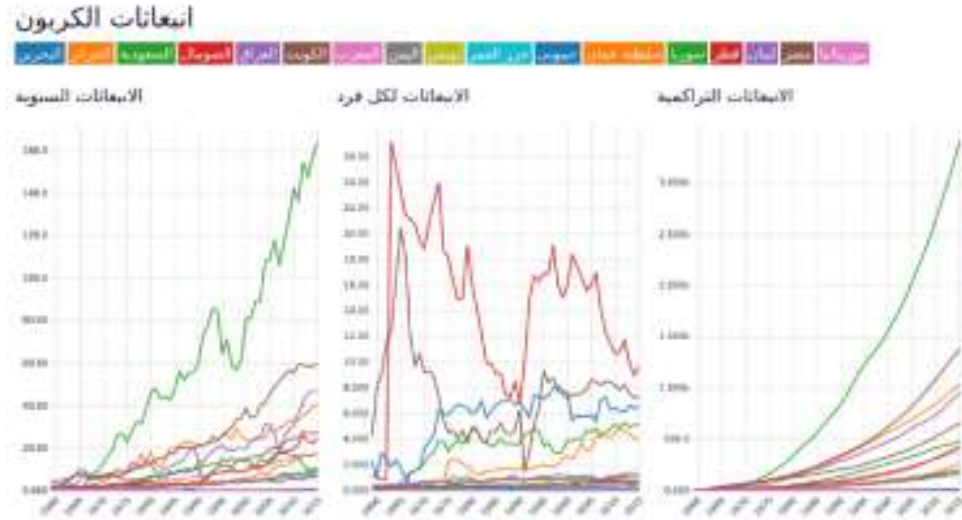

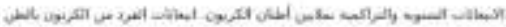

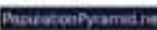

شالثكل ( ؛ ) رسم بيانى يوضح إنبعاثات الكربون لمعظم دول الوطن العربى ومقارنة إنبعاثات مصر الكربونية معهم، متضمنة الانبعاثات السنوية،

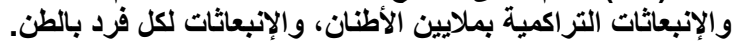

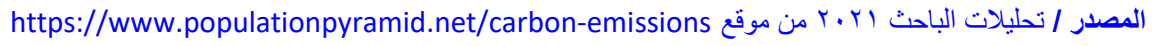

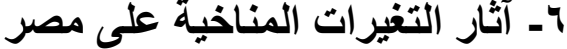

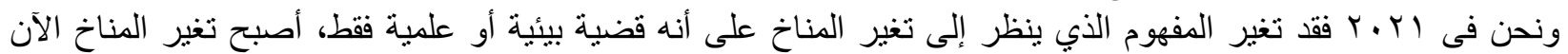

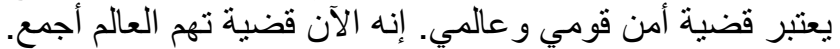

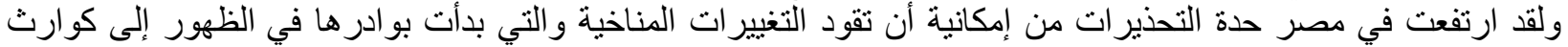

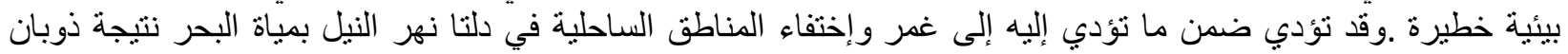

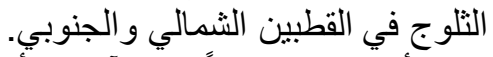

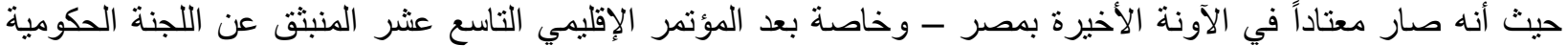

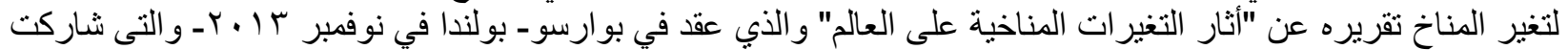

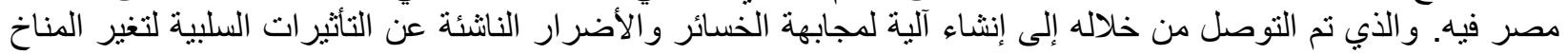


كما أن تداول منتديات وتقارير إعلامية وأحاديث لخبر اء بالبيئة وتقارير دولية ومحلية الخطر الزاحف باتجاة الدلتا المصرية

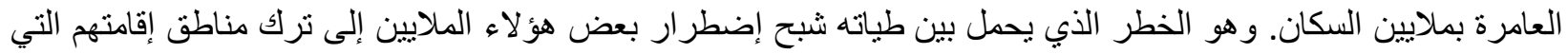

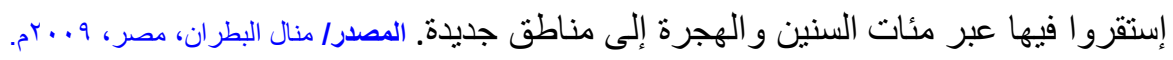

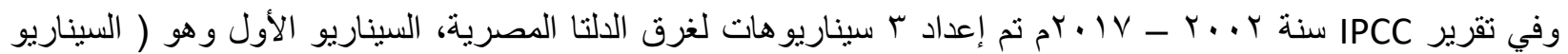

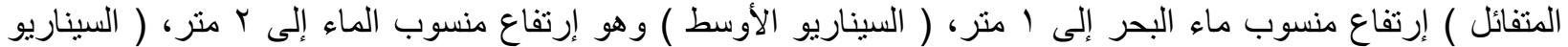

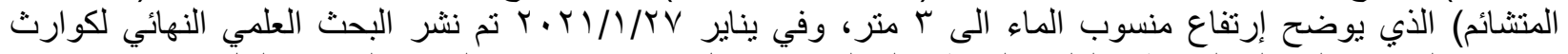

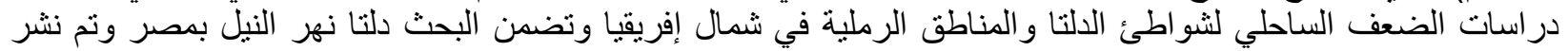

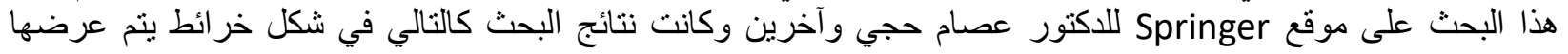

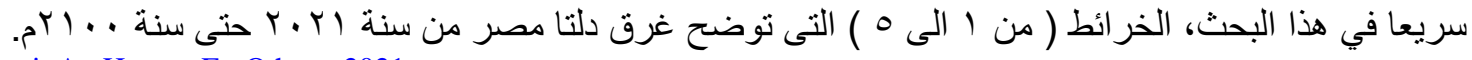
Source / Hzami, A., Heggy, E., Others, 2021

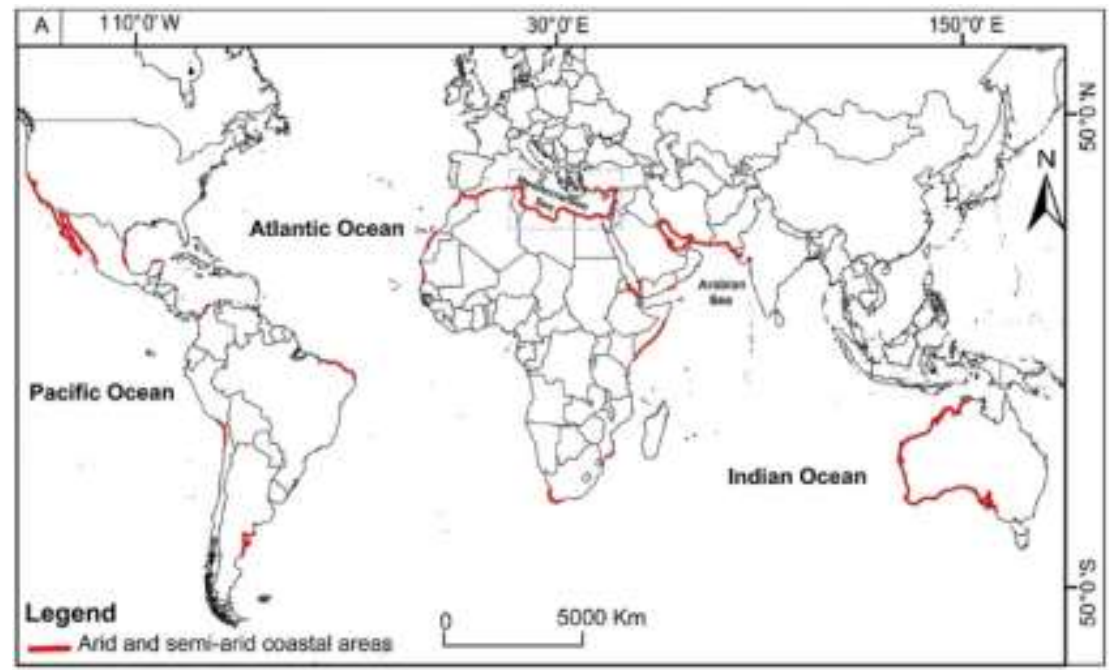

خريطة ( 1 ) أكثر السواحل عرضة للغرق جراء ظاهرة الاحتباس الحراري على مستوى العالم.

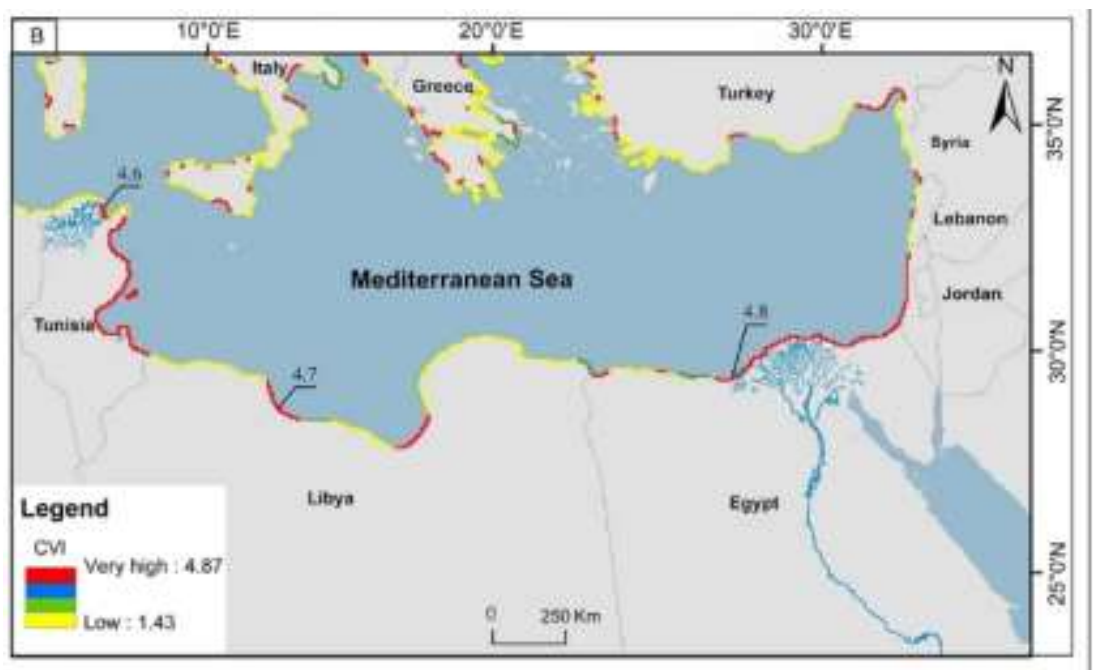

خريطة ( ץ ) مؤشر الضعف الساحلي بلتا مصر بأعلى درجة تساوي A, ؛ من AV, ؛ من معامل التقييم. 
دور التخطيط العمراني في مجابهة مخاطر غرق الدلتا جراء ظاهرة الإحتباس الحراري
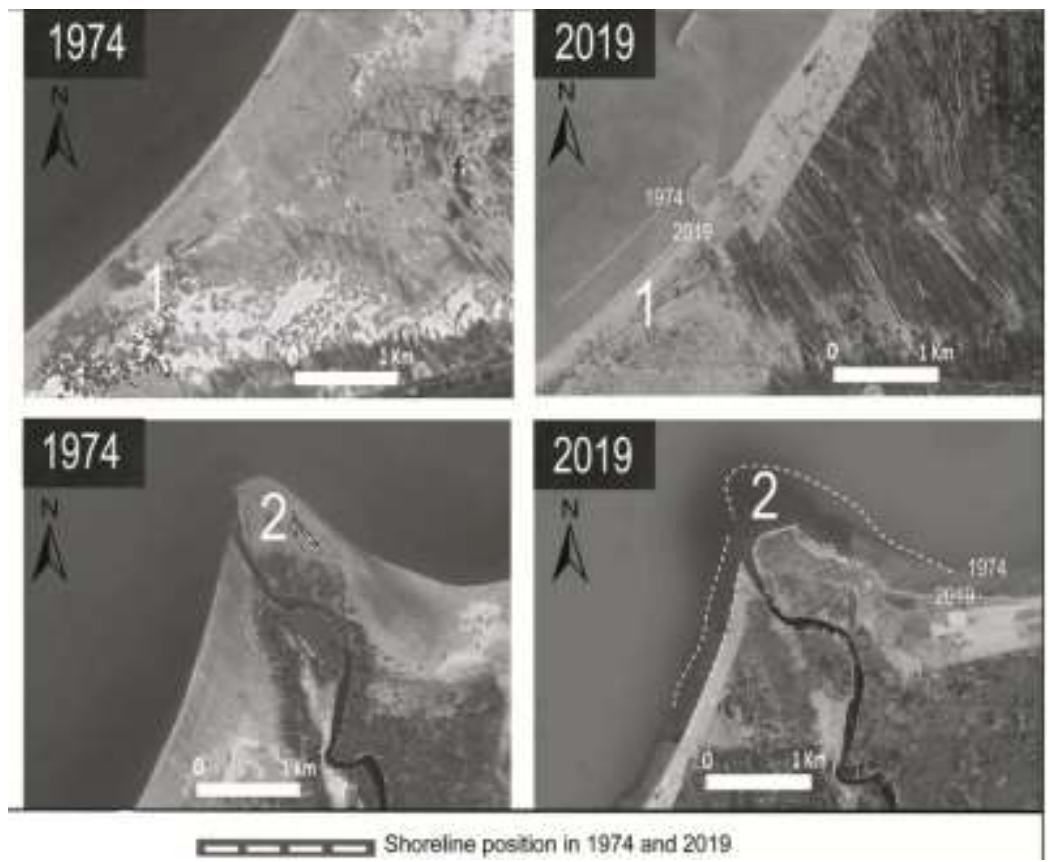

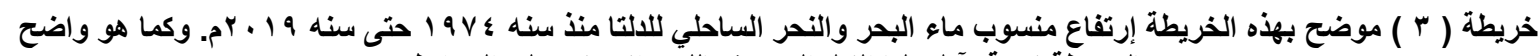
بالخريطة نسبة تآكل دلتا النيل المحدة باللون الابيض على الخرائط.

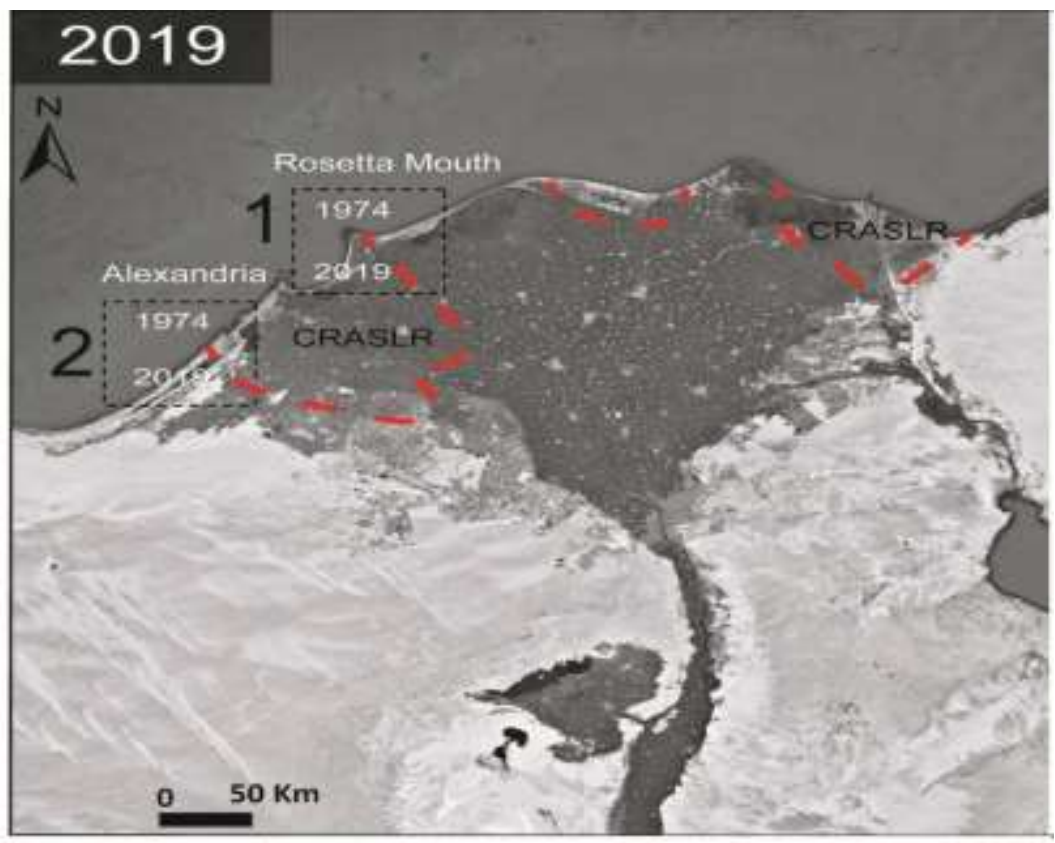

- CRASLR: Coastal Risk Areas to Sea Level Rise by 2100

خريطة ( ؛ ) بينما في هذه الخريطة موضح بها أماكن الخطر في دلتا النيل حتى سنه . . 1 ب م بناء على نتائج النحر الساحلي وإرتفاع منسوب

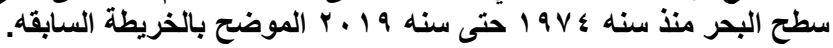


دور التخطيط العمراني في مجابهة مخاطر غرق الدلتا جراء ظاهرة الإحتباس الحراري

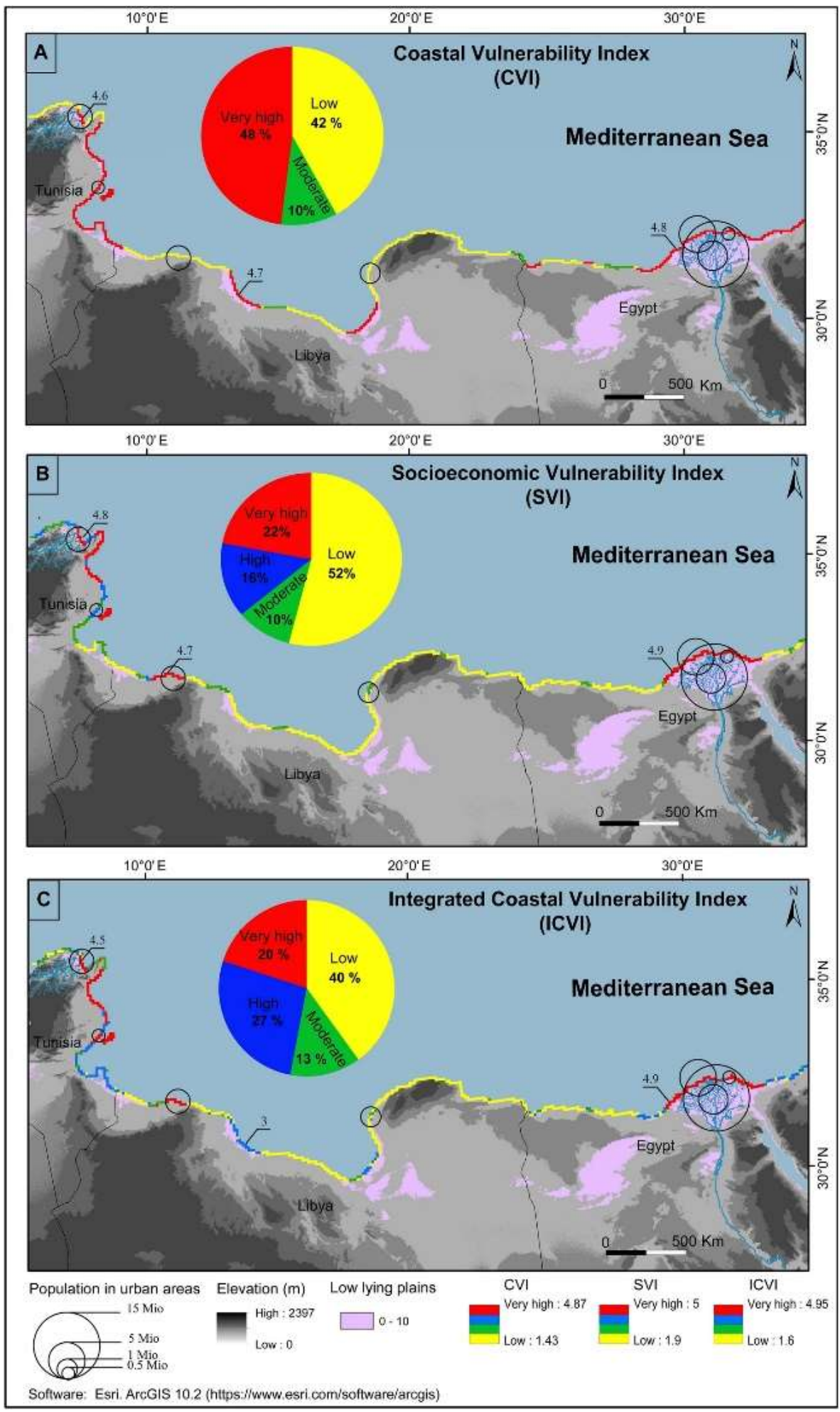

خريطة ( ه ) موضح بهذه الخرائط الثلاث مدى كمية تضرر دلتا نهر النيل سواء على المستوى الإقتصادي أو الإجتماعي أو على المستوى

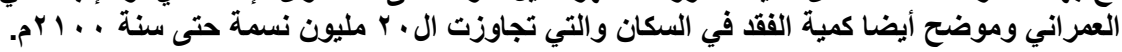




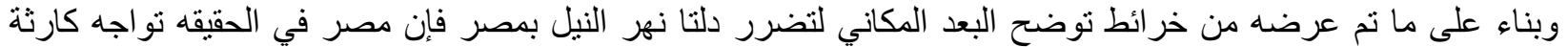

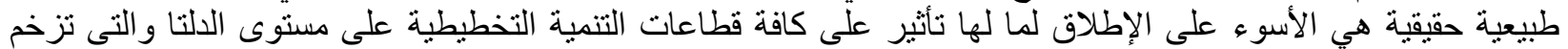

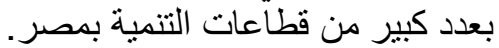
وفى إطار تقييم تأثير إرتفاع سطح البحر على السواحل المصرية هناك عناصر رئيسية نؤثر على الساحل الثمالي لمصر أ. إرتفاع سطح البحر

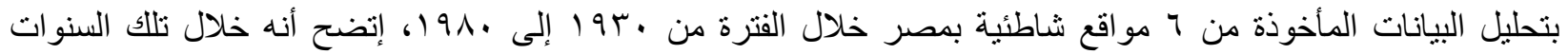

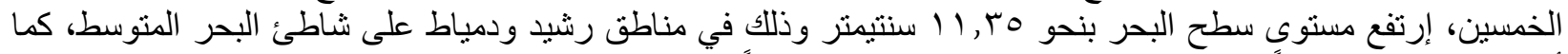

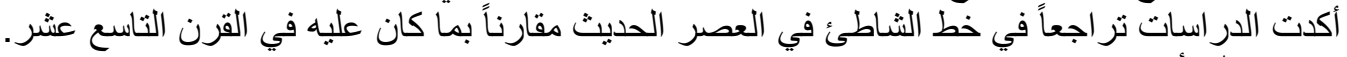

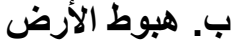

و هذه الظاهرة ينتج عنها إرتفاع ظاهري لسطح البحر نظر اً لهبوط الأرض نتيجة للتغيرات التكتونية في القشرة الأرضية في

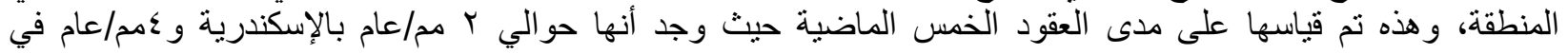

و هى الظاهرة الناتجة عن نحر الموجات أو التبار ات البحرية للثواطئ وينتج عنها إزاحة الرمال تدريجياً من منطقة وترسيبها

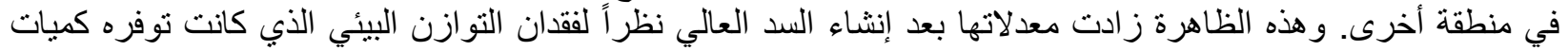
الطمي المترسبة على الثاطئ و التي تحملها مياه النيل إلى الثناطئ.

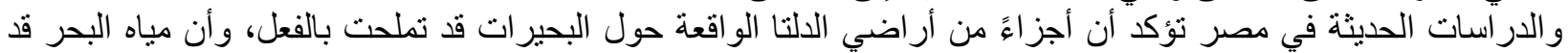

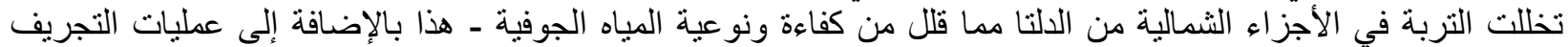

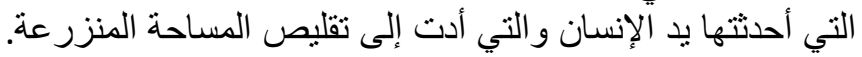

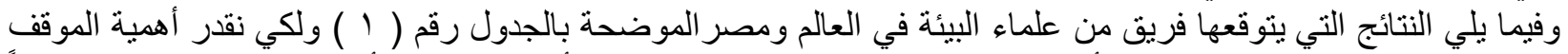

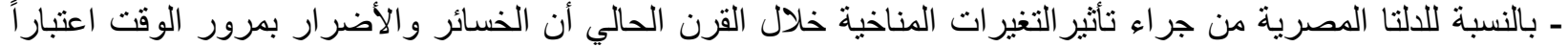

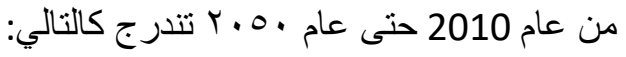

جدول ( 1 ) موقف دلتا مصر من جراء تأثير التغيرات المناخية

\begin{tabular}{|c|c|c|c|}
\hline الخسائر البشرية & الخسائر فى المساحة & العام & الزيادة في منسوب البحر \\
\hline 252000 نسمة & 144 144كم & 2010 & 18سم \\
\hline 545000 نسمة & 190 190 r r & 2030 & 30سم \\
\hline 1501200 نسمة & $r, 317$ & 2050 & 50 50 5م \\
\hline
\end{tabular}

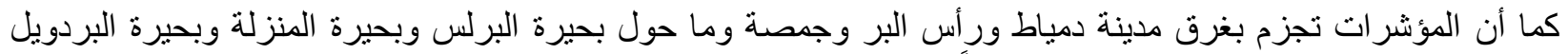

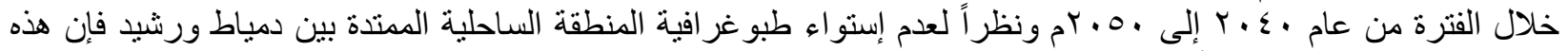

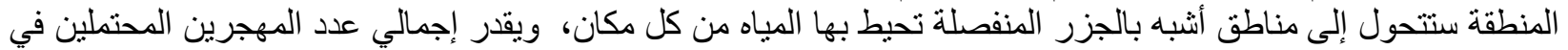

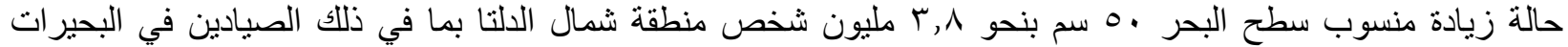

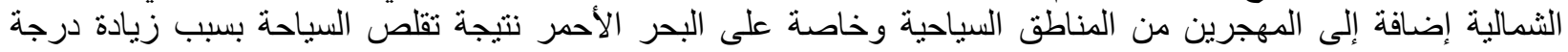

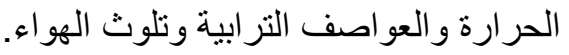

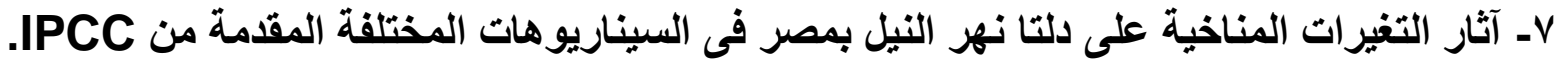

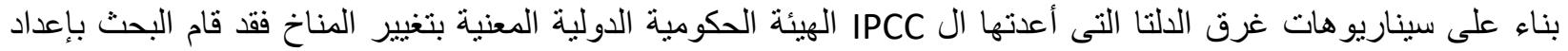

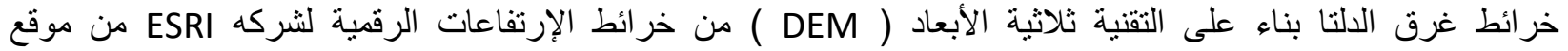
coastal.climatecentral.org/map المعلوماتية التخطيطية الخاصة بغرق الدلتا في كل سيناريو. 
أولا / فى حالة السيناريو المتفائل ( إرتفاع منسوب مياه البحر الى 1 متر حتى سنة . . ا ب م ).

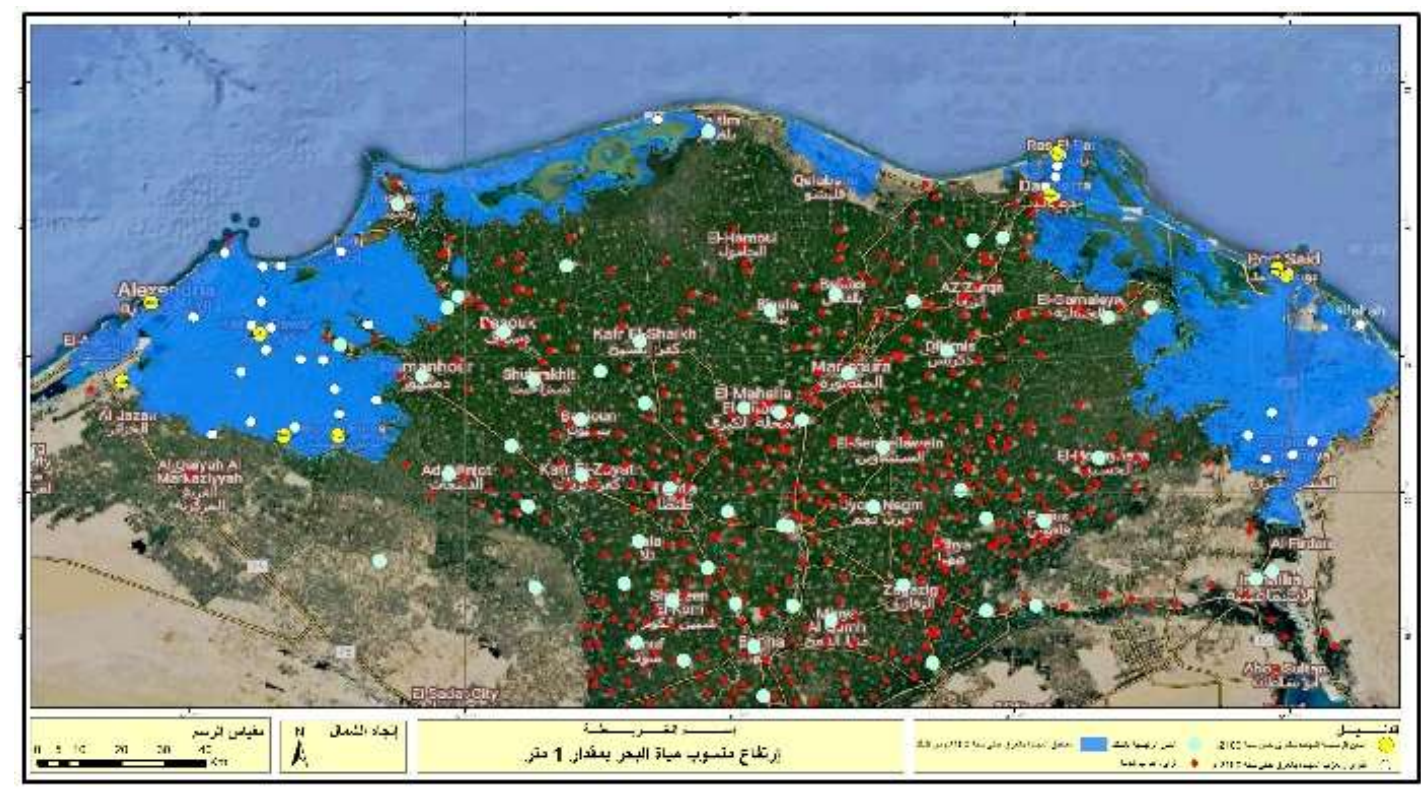

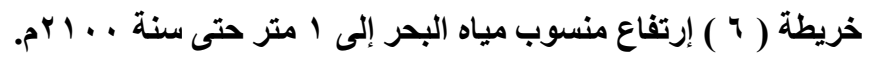

جدول ( ץ ) أوجه التغير الجيوفيزيقى على دلتا مصر فى حالة إرتفاع منسوب مياه البحر إلى 1 متر حتى سنة . . 1 ب م.

\begin{tabular}{|c|c|c|}
\hline فى حالة إرتفاع منسوب مياه البحر امتر & \multirow[t]{2}{*}{ 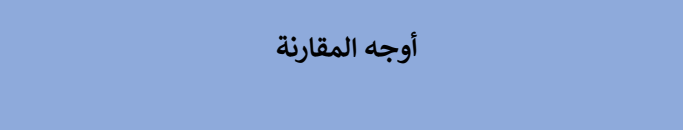 } & \multirow[t]{2}{*}{ b } \\
\hline السيناريو المتفائل & & \\
\hline 9 محافظات & عدد المحافظات المتضرره والمتأثرة جراء ظاهرة الإحتباس & 1 \\
\hline 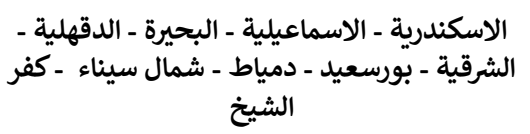 & أسماء المحافظات المتضرره جراء الظاهرة. & 2 \\
\hline 1210033.98 & مساحات مناطق المحافظات المتضررة بالفدان & 3 \\
\hline 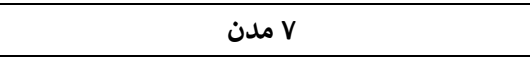 & عدد المدن الرئيسية المهددة بالغرق ( حضر وريف ) & 4 \\
\hline 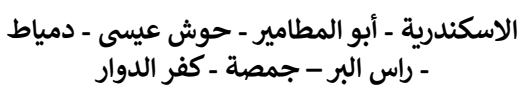 & أسماء المدن الرئيسية المهددة بالغرق & 5 \\
\hline 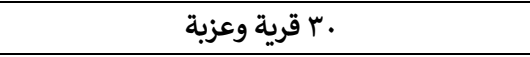 & عدد العزب والقرى المهددة بالغرق & 6 \\
\hline 35505.65 & مساحة الكتلة العمرانية المهددة بالغرق ( حضر وريف ) بالفدان & 7 \\
\hline 569.57 & أطوال شبكة الطرق المتضررة بالكم & 8 \\
\hline 966207.07 & مساحة الجزء المغمور بمياه البحر من السهل الفيضى ( دلتا & 9 \\
\hline $17.39 \%$ & نسبة الجزء المغمور بمياه البحر من السهل الفيضى ( دلتا النيل ) & 10 \\
\hline 926554.04 & مساحة الأراضى الزراعية المعرضة للغمر بمياه البحر المالحة & 11 \\
\hline
\end{tabular}


ثانيا / فى حالة السيناريو الأوسط ( إرتفاع منسوب مياه البحر إلى r متر حتى سنة . . 1 Y م ).

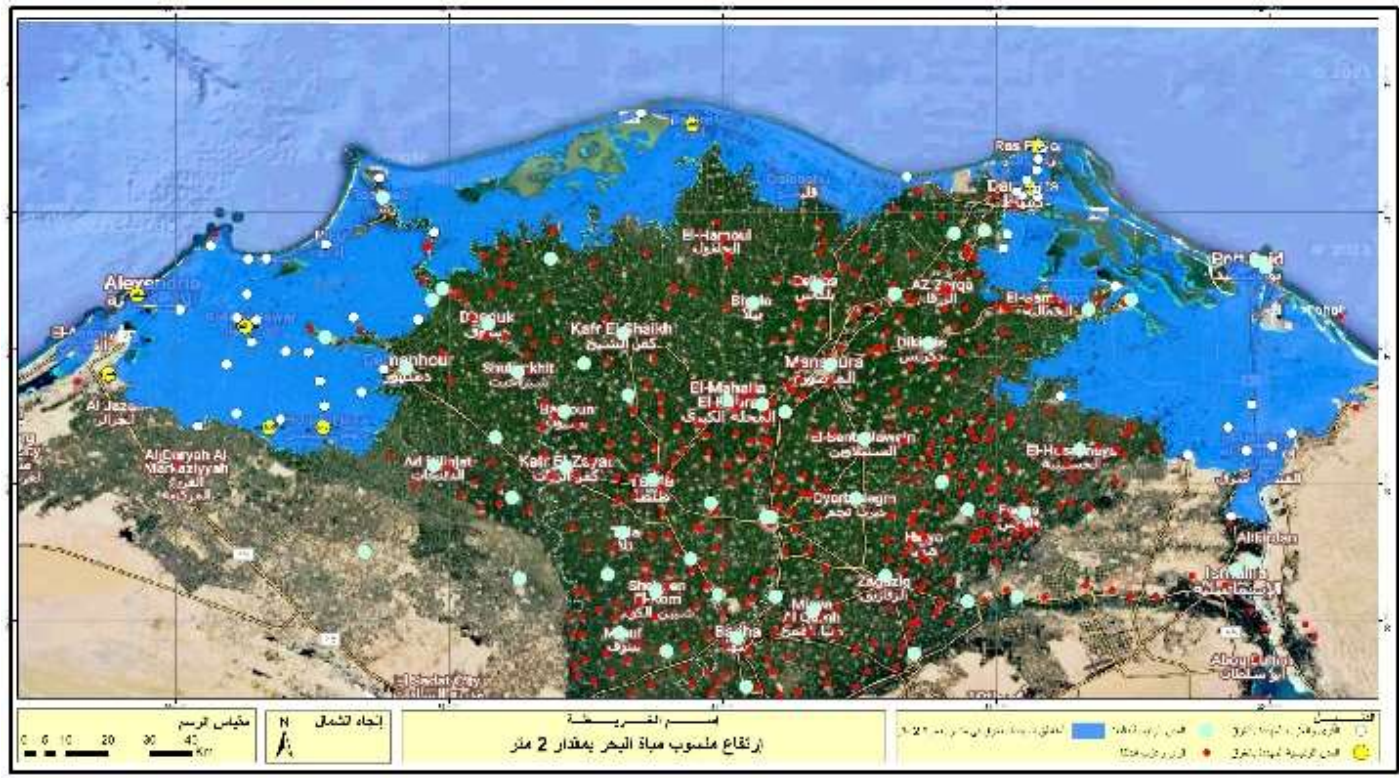

خريطة ( V ) إرتفاع منسوب مياه البحر إلى r متر حتى سنة . . . آم.

جدول ( r ) أوجه التغير الجيوفيزيقى على دلتا مصر فى حالة إرتفاع منسوب مياه البحر إلى ץ متر حتى سنة . . 1 آم.

\begin{tabular}{|c|c|c|}
\hline فى حالة إرتفاع منسوب مياه البحر r متر & \multirow[t]{2}{*}{ 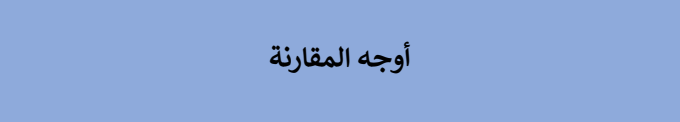 } & \multirow{2}{*}{ 5 } \\
\hline السيناريو الأوسط & & \\
\hline 9 محافظات & عدد المحافظات المتضررة والمتأثرة جراء ظاهرة الإحتباس & 1 \\
\hline الاسكندرية - الاسماعيلية - البحيرة - الدقهلية - الشرقية - بورسعيد - & أسماء المحافظات المتضررة جراء الظاهرة. & 2 \\
\hline 1644870.29 & مساحات مناطق المحافظات المتضررة بالفدان & 3 \\
\hline 9 مدن ومناطق حضرية & عدد المدن الرئيسية المهددة بالغرق ( حضر وريف ) & 4 \\
\hline الاسكندرية - العامرية - أبو المطامير - حوش عيسى - بلطيم - دمياط - راس & أسماء المدن الرئيسية المهددة بالغرق & 5 \\
\hline ع ع قرية وعزية & عدد العزب والقرى المهددة بالغرق & 6 \\
\hline 46453.57 & مساحة الكتلة العمرانية المهددة بالغرق ( حضر وريف ) بالفدان & 7 \\
\hline 782.10 & أطوال شبكة الطرق المتضررة بالكم & 8 \\
\hline 1440263.47 & مساحة الجزء المغمور من السهل الفيضى بالفدان & 9 \\
\hline $25.92 \%$ & نسبة الجزء المغمور بمياه البحر من السهل الفيضى ( دلتا النيل ) & 10 \\
\hline 1386646.71 & مساحة الأراضى الزراعية المعرضة للغمر بالفدان & 11 \\
\hline
\end{tabular}


دور التخطيط العمراني في مجابهة مخاطر غرق الالتا جراء ظاهرة الإحتباس الحراري

ثالثا / فى حالة السيناريو المتشائم ( إرتفاع منسوب مياه البحر إلى ب متر حتى سنة . . 1 ب م ).

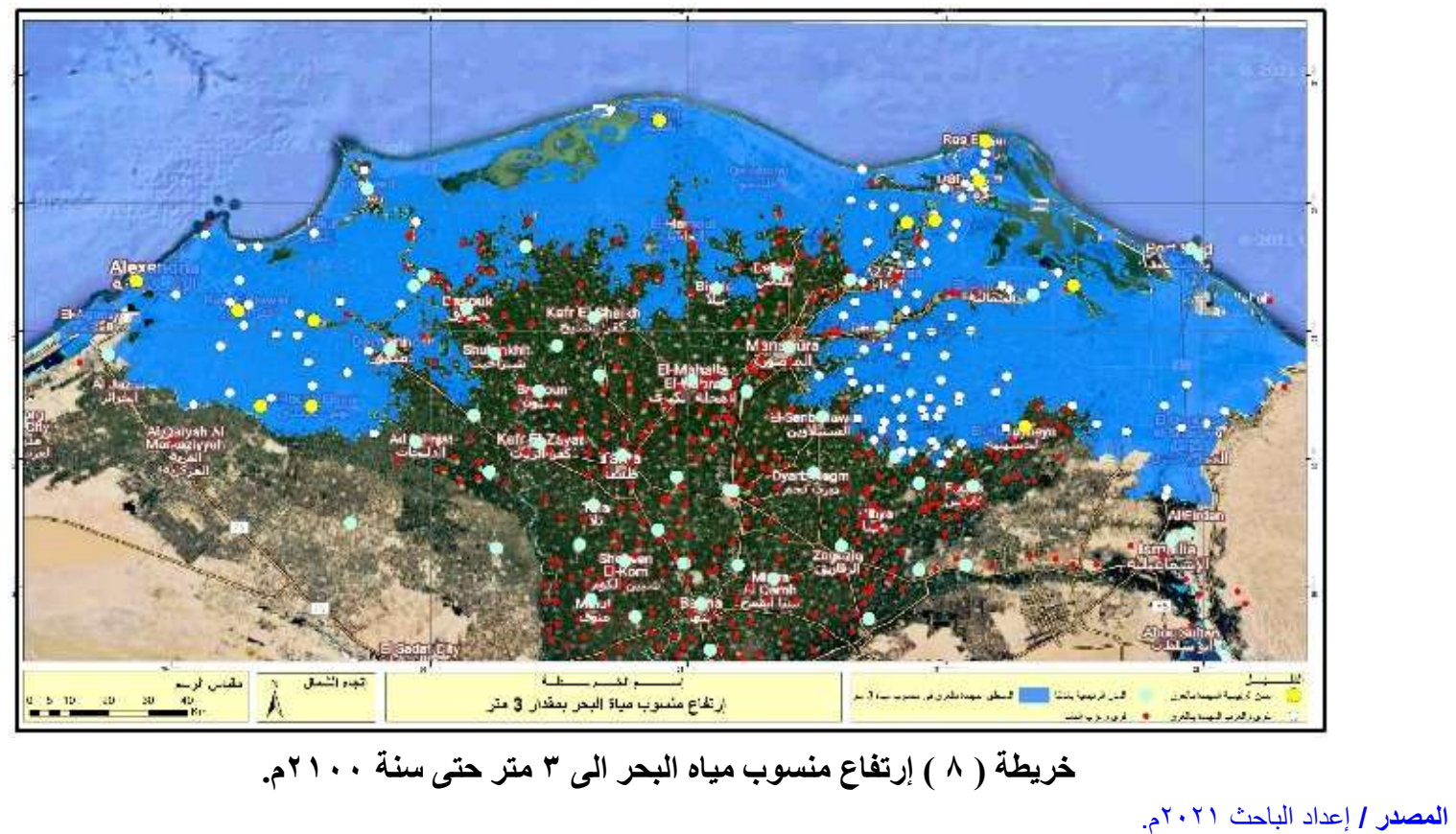

جدول ( ؛ ) أوجه التغير الجيوفيزيقى على دلتا مصر فى حالة إرتفاع منسوب مياه البحر إلى ب متر حتى سنة . . 1 بم. 
دور التخطيط العمراني في مجابهة مخاطر غرق الدلتا جراء ظاهرة الإحتباس الحراري

\begin{tabular}{|c|c|c|}
\hline فى حالة إرتفاع منسوب مياه البحر بامتر & 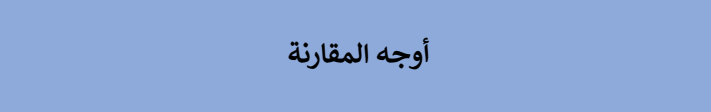 & b \\
\hline •ا محافظات & عدد المحافظات المتضررة والمتأثرة جراء الظاهرة & 1 \\
\hline 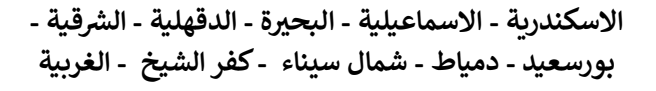 & أسماء المحافظات المتضررة جراء الظاهرة. & 2 \\
\hline 2543633.15 & مساحات مناطق المحافظات المتضررة بالفدان & 3 \\
\hline با با مدينة ومنطقة حضرية & عدد المدن الرئيسية المهددة بالغرق ( حضر وريف ) & 4 \\
\hline 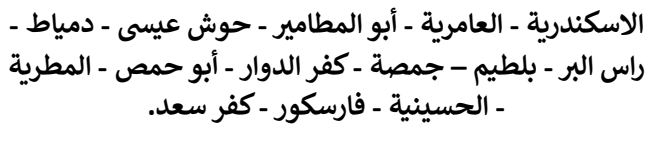 & أسماء المدن الرئيسية المهددة بالغرق & 5 \\
\hline 1· 1 ا قرية وعزبة & عدد العزب والقرى المهددة بالغرق & 6 \\
\hline 81148.13 & مساحة الكتلة العمرانية المهددة بالغرق ( حضر وريف ) بالفدان & 7 \\
\hline 1165.20 & أطوال شبكة الطرق المتضررة بالكم & 8 \\
\hline 2339702.28 & مساحة الجزء المغمور بمياه البحر من السهل الفيضى ( دلتا النيل ) & 9 \\
\hline $42.11 \%$ & نسبة الجزء المغمور بمياه البحر من السهل الفيضى ( دلتا النيل ) & 10 \\
\hline 2245763.89 & مساحة الاراضى الزراعية المعرضة للغمر بالفدان & 11 \\
\hline
\end{tabular}

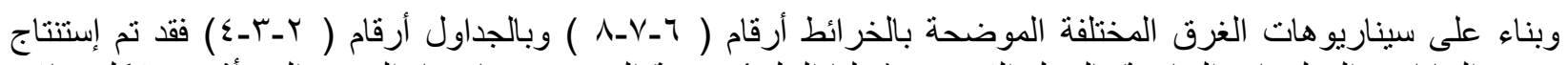

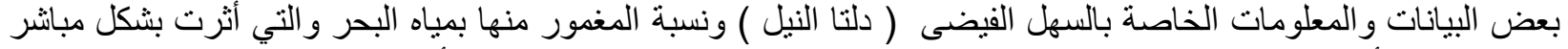

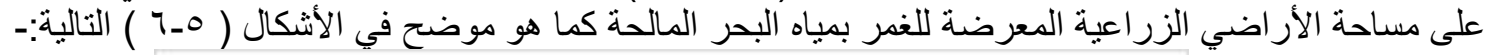

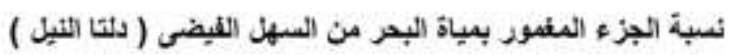

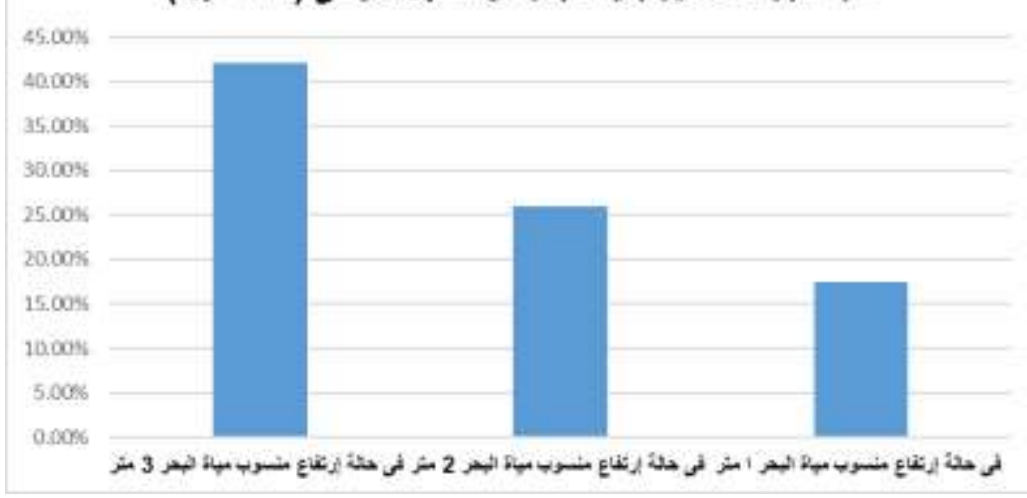

شكل ( • ) رسم بيانى يوضح نسب الجزء المغمور بمياه البحر من السهل الفيضى ( دلتا النيل ) فى السيناريوهات المختلفة.

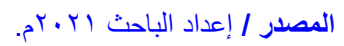




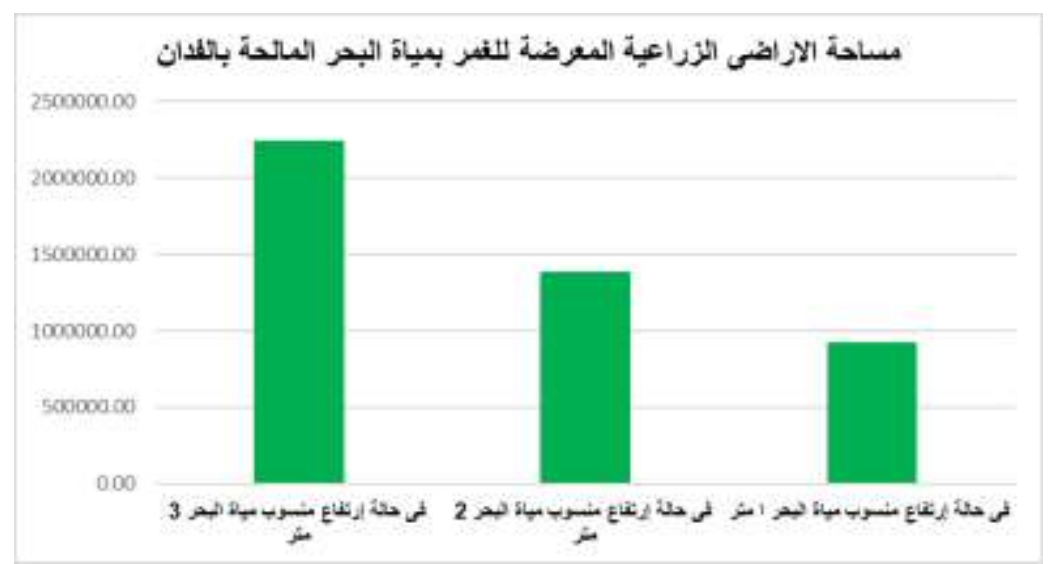

شكل ( T ) رسم بيانى يوضح مساحات الأراضى الزراعية بالفدان المغمورة بمياه البحر فى السيناريوهات المختلفة.

المصدر / إعداد الباحث اب ·rم.

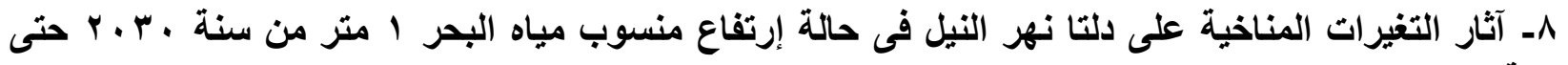

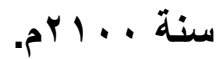
وبناء على نتائج التقارير الدولية والبحثية الخاصة بالتغير المناخي وتاثيره على دلتا نهر النيل بمصر فقد قام البحث بإعتماد

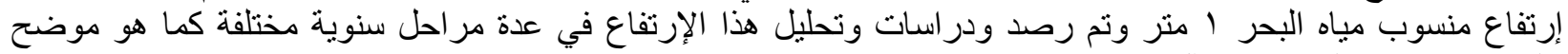
بالخرائط (من 9 إلى ب ( ) كالآتي:

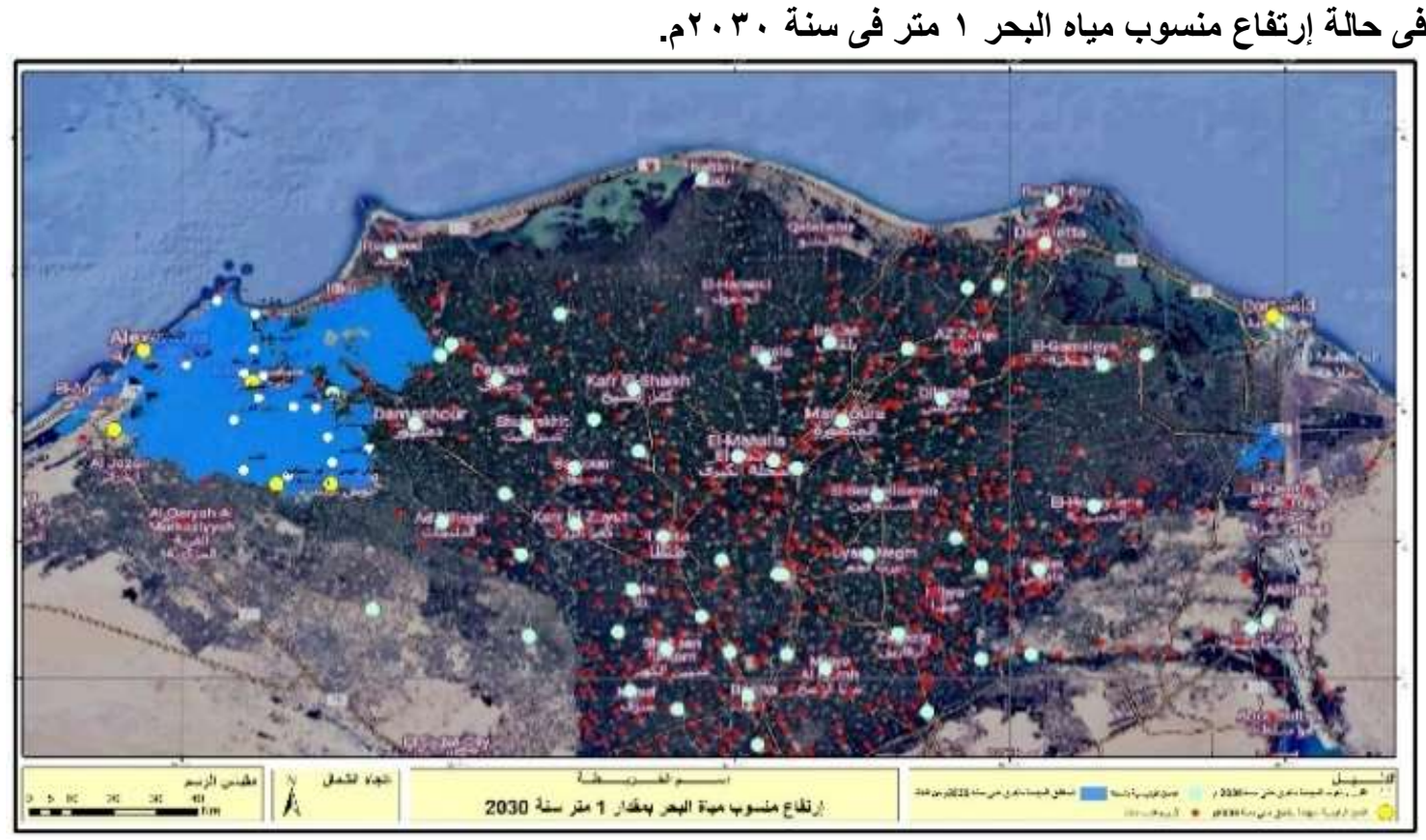

خريطة (9 ) فى حالة إرتفاع منسوب مياه البحر الى ا متر سنة . r • rم. 
جدول ( • ) أوجه التغير الجيوفيزيقى على دلتا مصر فى حالة إرتفاع منسوب مياه البحر إلى 1 متر سنة • ب • م.

\begin{tabular}{|c|c|c|}
\hline 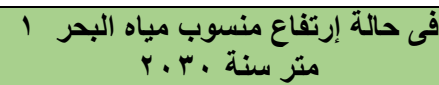 & أوجه المقارنة & م \\
\hline آ مدن ومناطق حضرية & عدد المدن الرئيسية المهلدة بالغرق ( حضر وريف ) & 1 \\
\hline حوش عيسى - كفر الدوار - العامية - بورسعيد - المطامير & أسماء المدن الرئيسية المهددة بالغرق & 2 \\
\hline 0 ا م قرية وعزبة & عداد العزب والقرى المهددة بالغرق & 3 \\
\hline 23126.12 & مساحة الكتلة العمرانية المهددة بالغرق ( حضر وريف ) بالفدان & 4 \\
\hline 436777.64 & مساحة الجزء المغمور من السهل الفيضى ( دلتا النيل ) بالفدان & 5 \\
\hline $7.88 \%$ & نسبة الجزء المغمور بمياه البحر من السهل الفيضي ( دلتا النيل ) & 6 \\
\hline
\end{tabular}

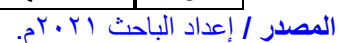

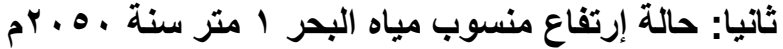

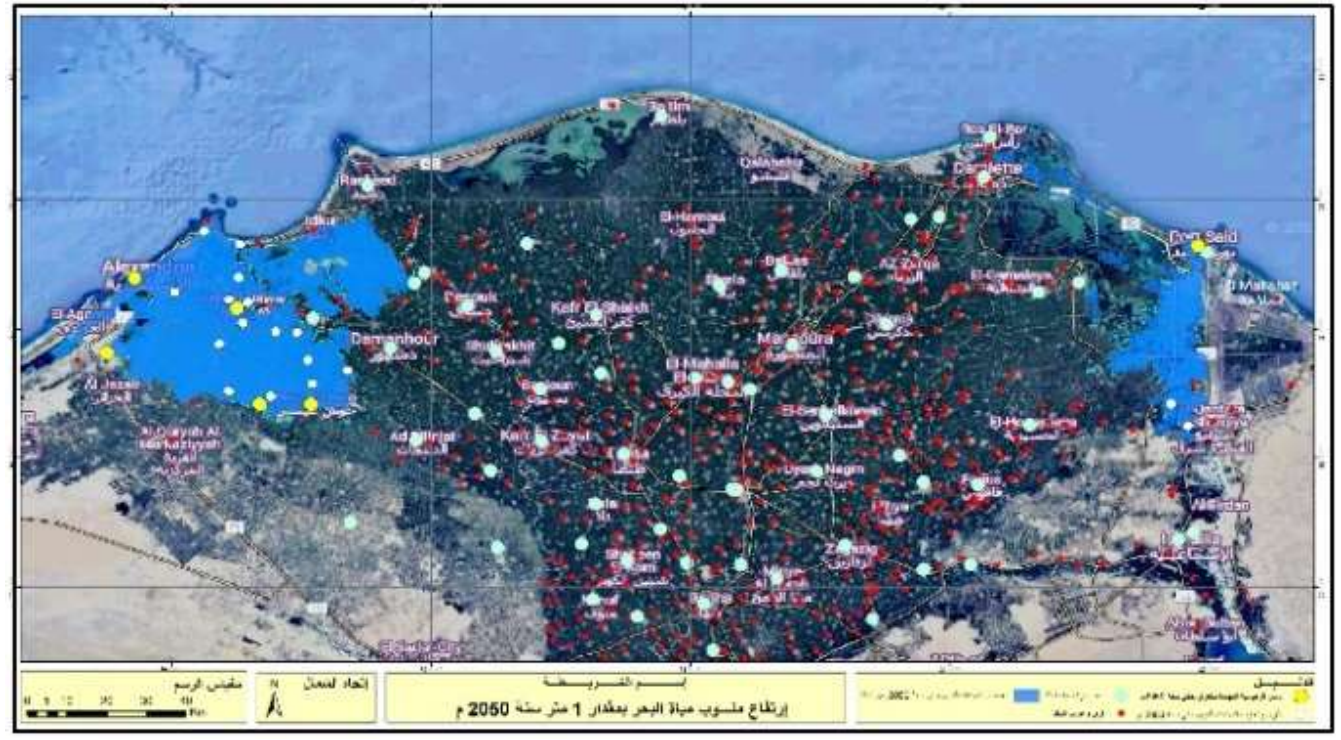

خريطة ( • 1 ) فى حالة إرتفاع منسوب مياه البحر إلى ا متر سنة ــ ـ بم.

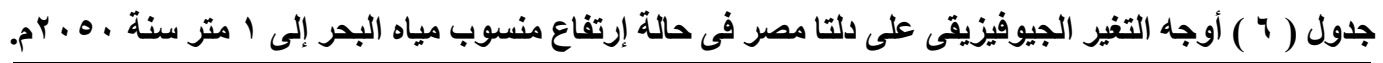

\begin{tabular}{|c|c|c|}
\hline 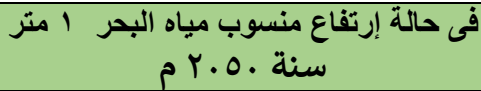 & أوجه المقارنة & p \\
\hline I مدن ومناطق حضرية & عدد المدن الرئيسية المهادة بالغرق ( حضر وريف ) & 1 \\
\hline حوش عيسى - كفر الدوار - العامرية - أبورسعيد - المطيد & أسماء المدن الرئيسية المهددة بالغرق & 2 \\
\hline V V ا قرية وعزبة & عدد العزب والقرى المهددة بالغرق & 3 \\
\hline 23225.21 & مساحة الكتلة العمرانية المهددة بالغرق ( حضر وريف ) & 4 \\
\hline 538270.56 & مساحة الجزء المغمور من السهل الفيضى ( دلتا النيل ) & 5 \\
\hline $9.71 \%$ & نسبة الجزء المغمور بمياه البحر من السهل الفيضى ( دلتا & 6 \\
\hline
\end{tabular}


ثالثا: فى حالة إرتفاع منسوب مياه البحر 1 متر فى سنة • V. rم.

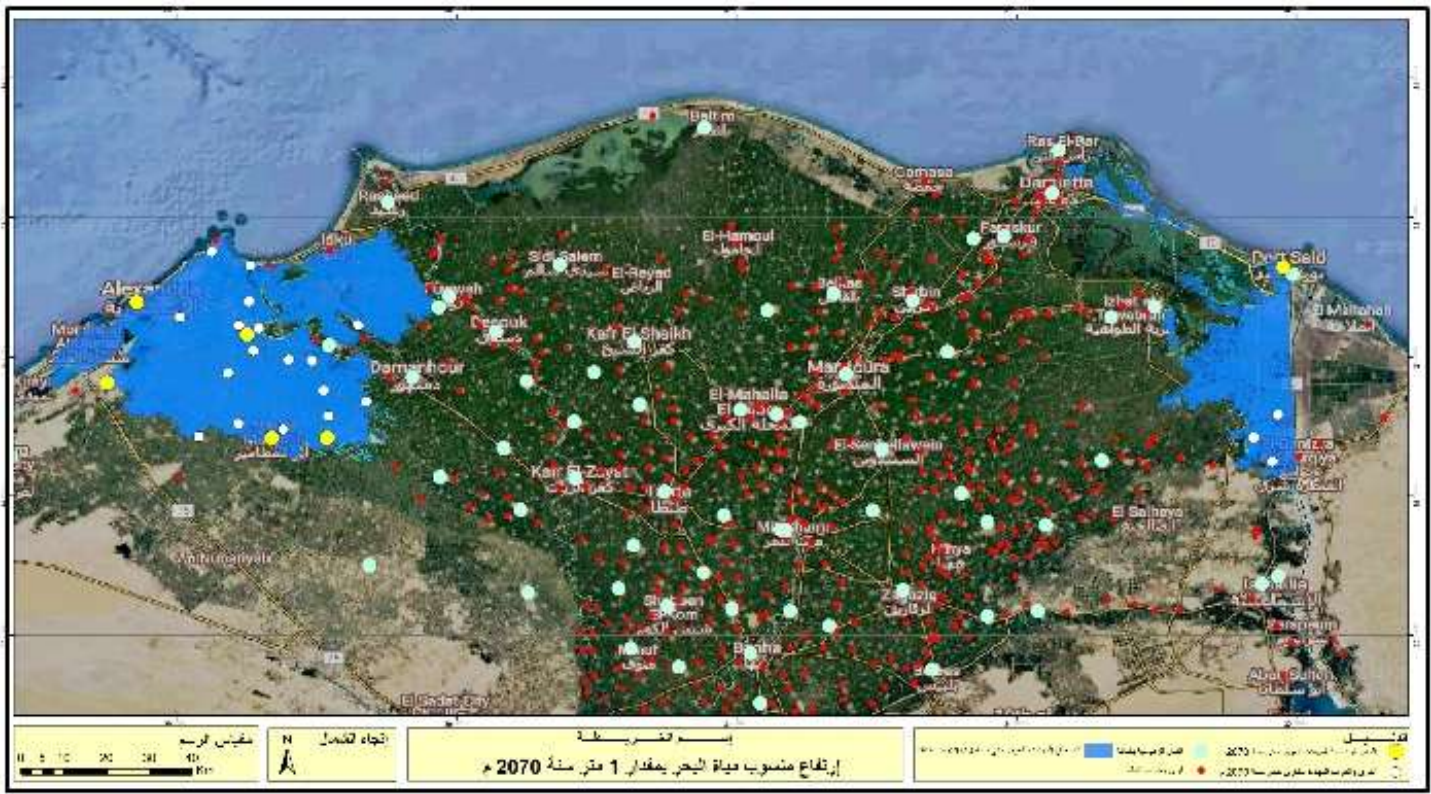

خريطة ( 11 ) فى حالة إرتفاع منسوب مياه البحر إلى 1 متر سنة •V • Yم.

جدول ( V ) أوجه التغير الجيوفيزيقى على دلتا مصر فى حالة إرتفاع منسوب مياه البحر إلى 1 متر سنة • V • Pم.

\begin{tabular}{|c|c|c|}
\hline 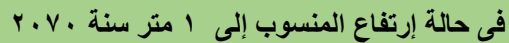 & أوجه المقارنة & م \\
\hline 1 آ مدن ومناطق حضرية & عدد المدن الرئيسية المهددة بالغرق ( حضر وريف ) & 1 \\
\hline الاسكندرية - العامرية - أبو المطامير - حوش - بوشيد & أسماء المدن الرئيسية المهلدة بالغرق & 2 \\
\hline 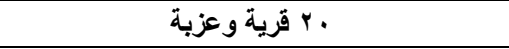 & عدد العزب و القرى المهددة بالغرق & 3 \\
\hline 29530.42 & مساحة الكتلة العمرانية المهلدة بالغرق ( حضر وريف ) بالفدان & 4 \\
\hline 604245.98 & مساحة الجزء المغمور من السهل الفيضى ( دلتا النيل ) بالفدان & 5 \\
\hline $10.90 \%$ & نسبة الجزء المغهور بمياه البحر من السهل الفيضى ( دلت النيل ) & 6 \\
\hline
\end{tabular}


رابعا: فى حالة إرتفاع منسوب مياه البحر 1 متر فى سنة . . 1 آم.

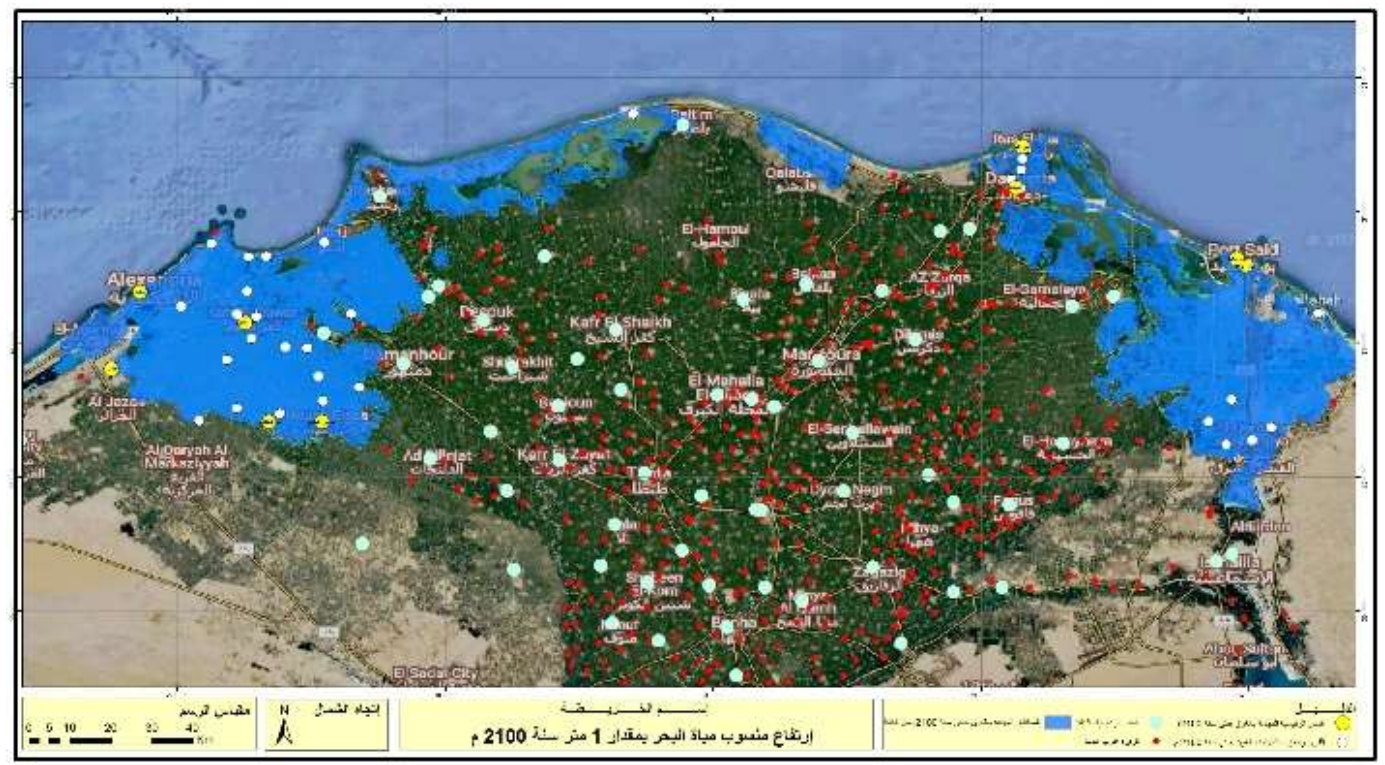

خريطة ( r l ) فى حالة إرتفاع منسوب مياه البحر إلى 1 متر سنة . . اب م.

جدول ( ^ ) أوجه التغير الجيوفيزيقى على دلتا مصر فى حالة إرتفاع منسوب مياه البحر إلى ا متر سنة . . 1 ب م.

\begin{tabular}{|c|c|c|}
\hline 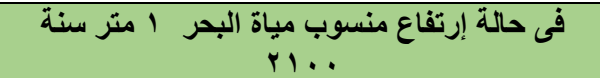 & أوجه المقارنة & م \\
\hline ^ مدن ومناطق حضرية & عدد المدن الرئيسية المهددة بالغرق ( حضر وريف ) & 1 \\
\hline 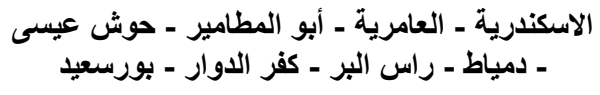 & أسماء المدن الرئيسية المهددة بالغرق & 2 \\
\hline 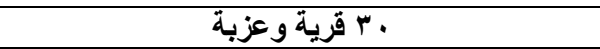 & عدد العزب والقرى المهلدة بالغرق & 3 \\
\hline 35505.65 & مساحة الكتلة العمر انية المهذدة بالغرق ( حضر وريف ) بالفدان & 4 \\
\hline 966207.07 & مساحة الجزء المغور من السهل الفيضى ( دلتا النيل ) بالقدان & 5 \\
\hline $17.39 \%$ & نسبة الجزء المغمور بمياه البحر من السهل الفيضى ( دلتا النيل ) & 6 \\
\hline
\end{tabular}

\section{9ـ تحليل عام لمشكلة البحث}

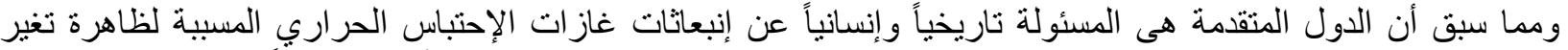

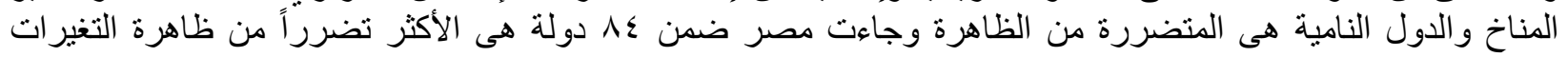

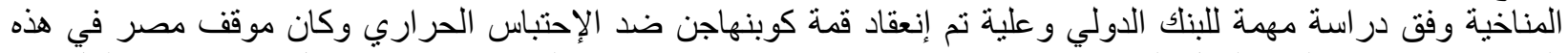

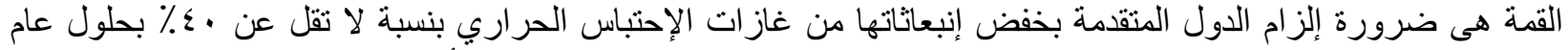

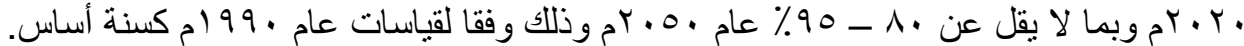

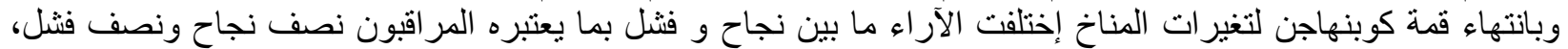

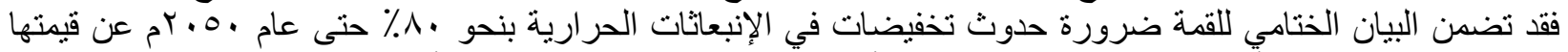

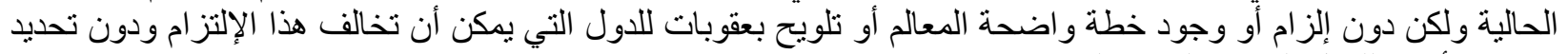
حصص أيضا للاول الكبرى المسببه لهذه الإنبعانات. 


\section{1 أـ تحليل عام لمشكلة غرق الالتا}

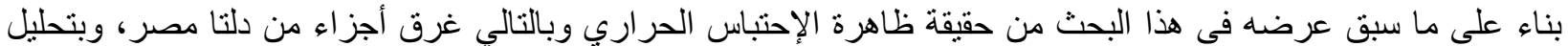

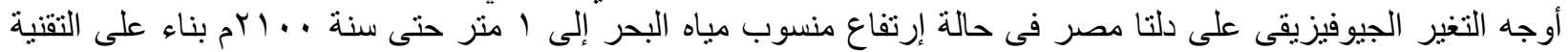

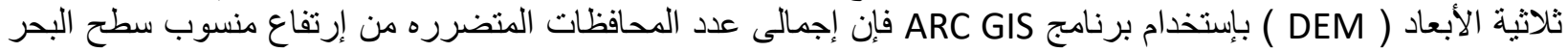

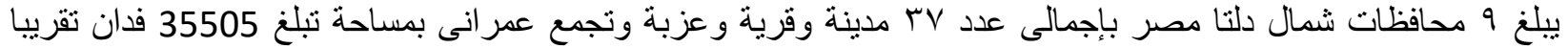
بينما تبلغ إجمالى مساحة الأراضي الزراعية المغورة بالئل بالمياه المالحة

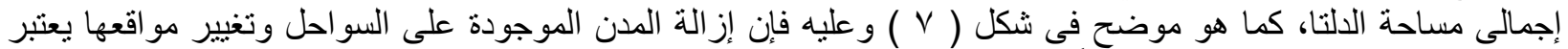

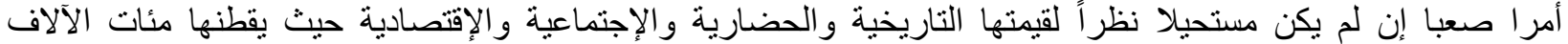
وبعضها الملابين من السكان الذين إرتبطوا بها و إرتبطت بهم.

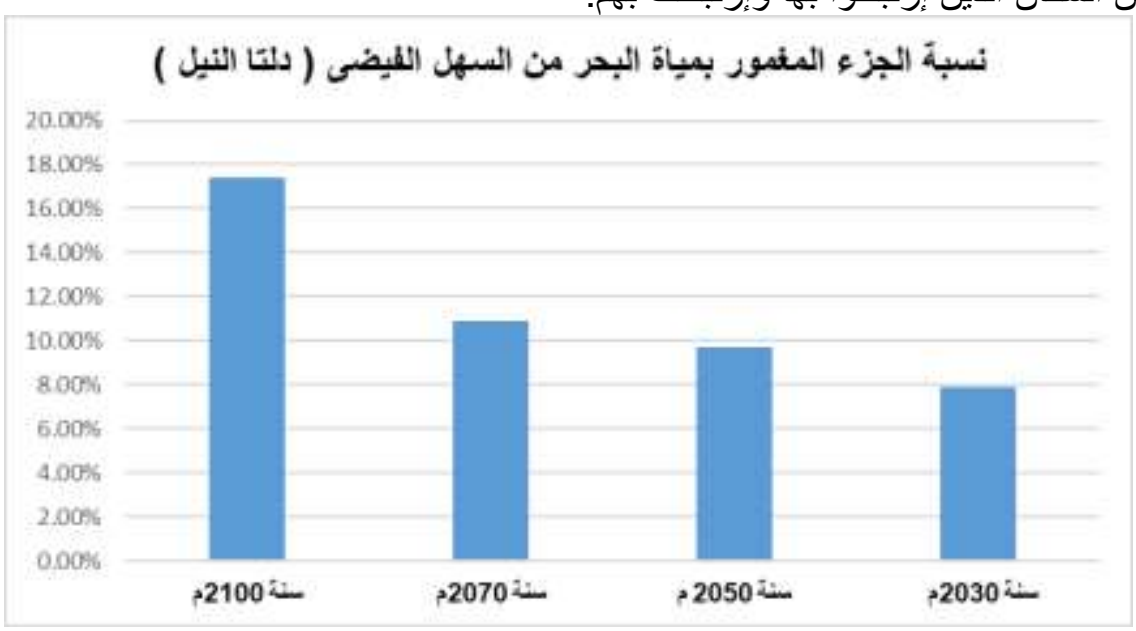

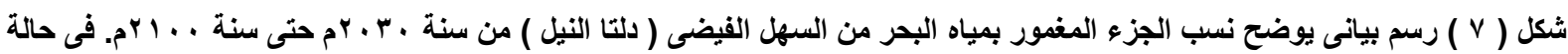

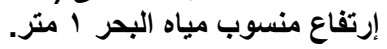

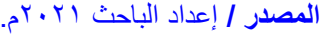

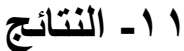

من خلال الدراسة التحليلية فى هذا البحث يمكن طرح بعض أفكار لدور التخطيط العمر اني في مواجهة كارثنة غرق الدألتا

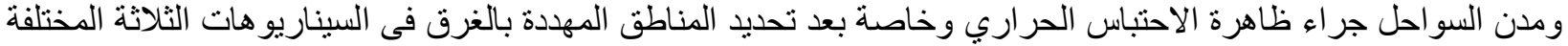

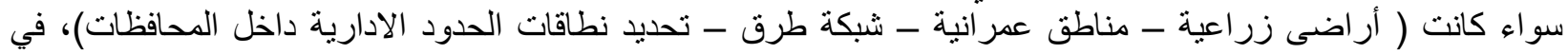
إيقاف نمو الددن و التتمية العمر انية على إمتداد الثريط الساحلي و التنمية في الاتجاهات الأخرى.

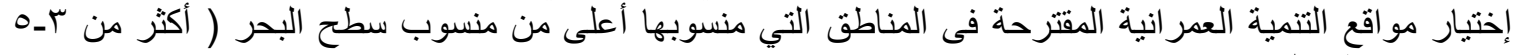
منر فوق سطح البحر ).

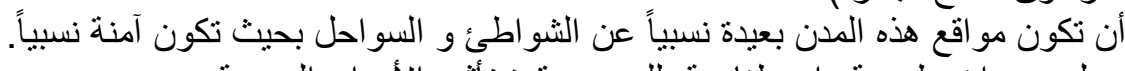

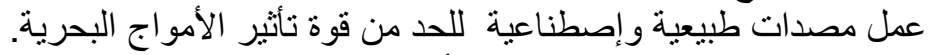

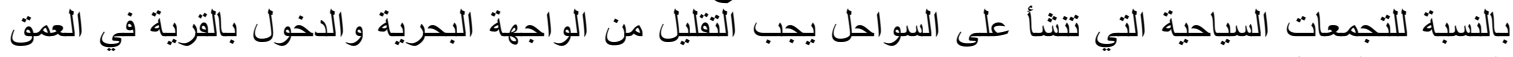

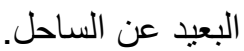

$$
\text { • زرع الأشجار و الحدائق و المسطحات الخضر اء على شبكة الطرق. }
$$

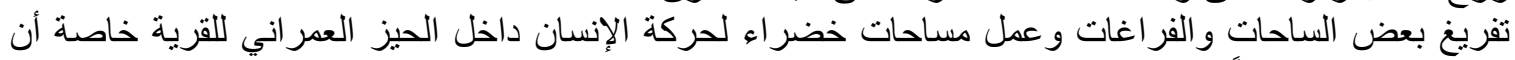

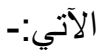

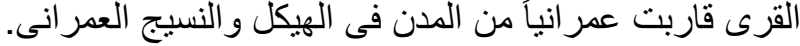

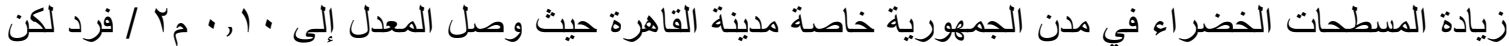

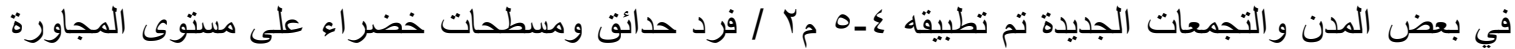

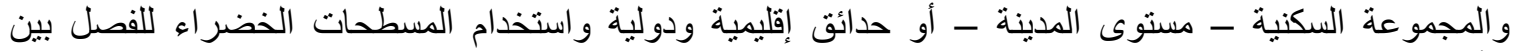
الأحياء السكنية وبعضها البعض الامر الذى يقلل من ارتفاع درجة حرارة الارض. 
• استخدام مشروعات الطاقه النظيفه كدعم لاستخدام اليات الطاقه النظيفه CDM حيث أن نسبه السطوع الثمسيه

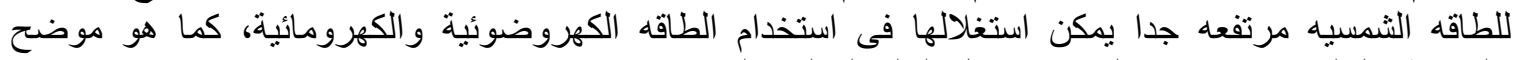

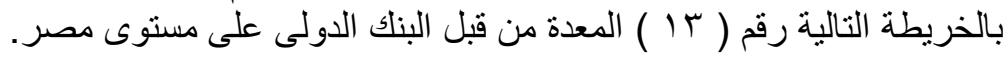

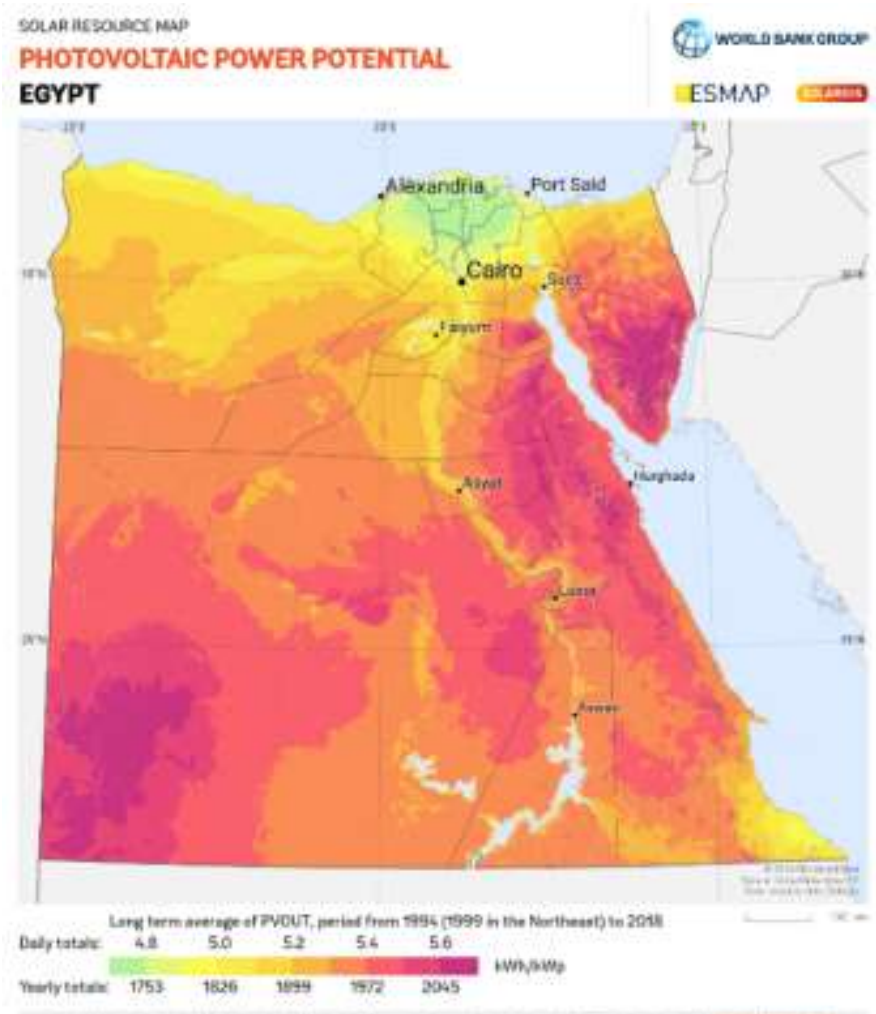

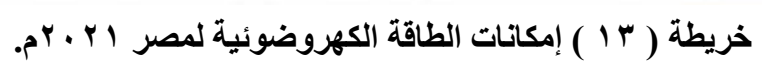

Sourcel https://globalsolaratlas.info/download/egypt

• نهج و إتباع نظرية الاقلمة (التكيف) التخطيطية يلزم ذللك التكيف مع الوضع الحالى فى كآفة قطاعات التنمية، كما هو

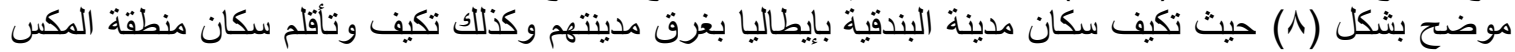

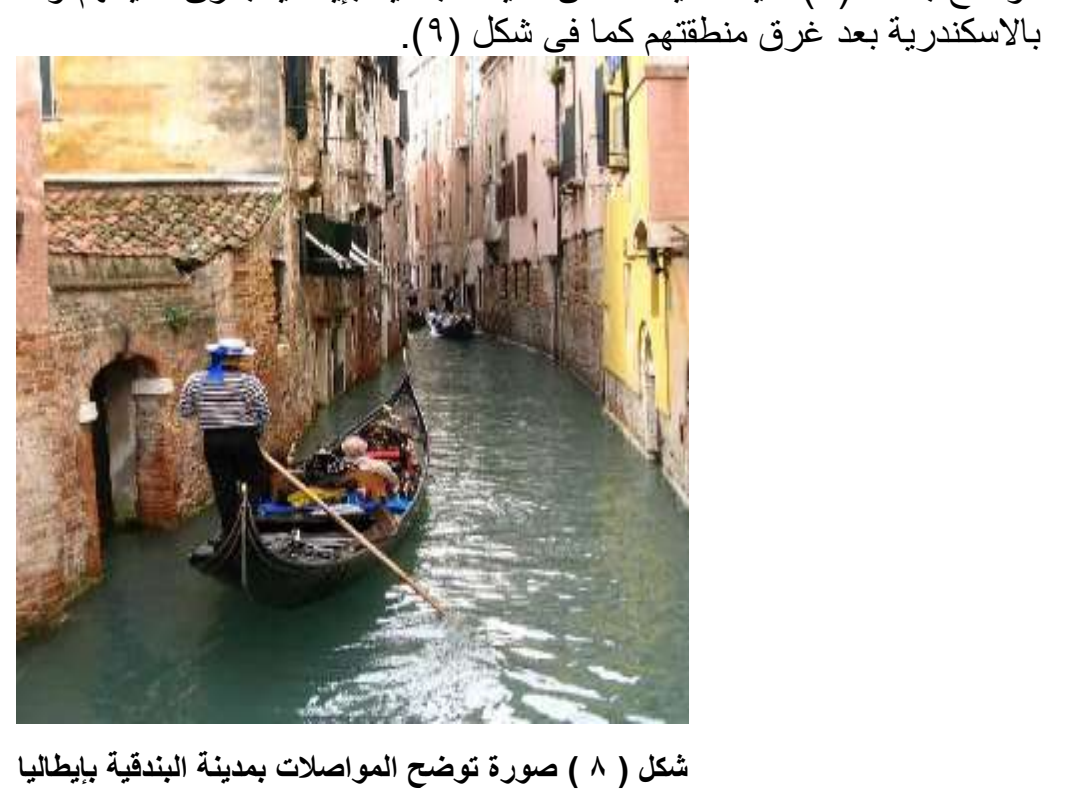




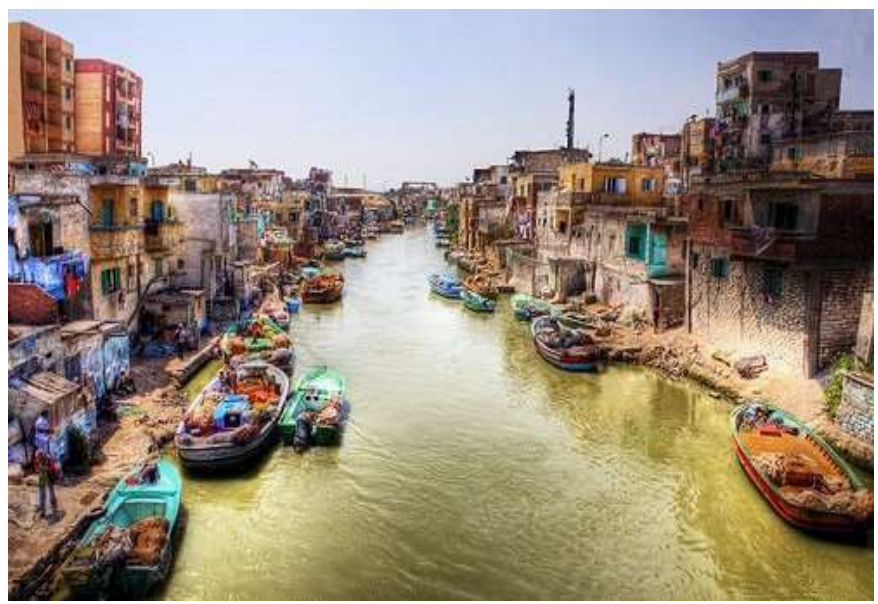

شكل ( 9 ) ) تكيف سكان منطقة المكس بالاسكندرية بعد الغرق

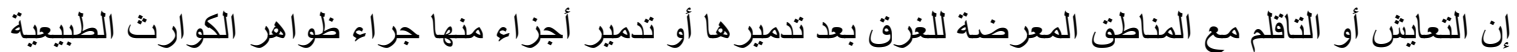

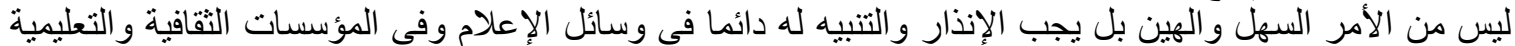
وإرساخ فكرة ومفهوم الأقلمة مع الظروف بل القهرية النى قد تحدث في تللك المناطق.

\section{r ا ـالتوصيات والمقترحات:}

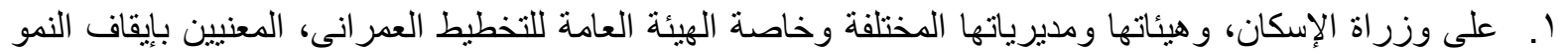

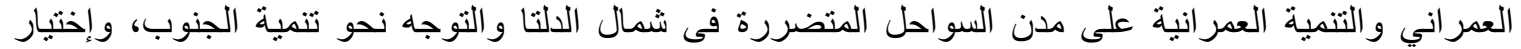

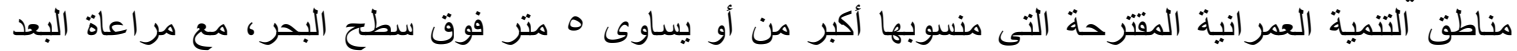

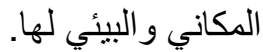
r. على هيئة حمائة الشو اطئ أن تعمل مصدات طبيعية و إصطناعية للحد من قوة تأثير الامواج البحرية والمسببة لعملية نحر الشواطئ. r. أن تقوم هيئة الثروة السمكية بإتخاذ اللازم فى إمكانية تحول مخاطر غرق المناطق الساحلية شمال الدلتا الى نقاط

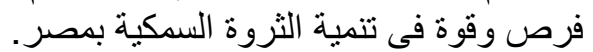

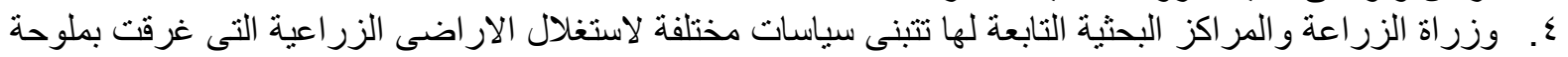
مياه البحر فى الزراع الزعات المناسبة لذلك.

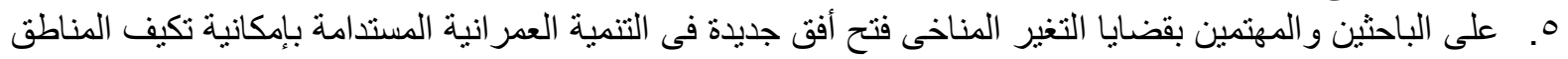

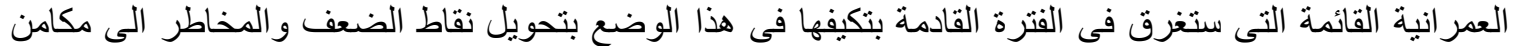

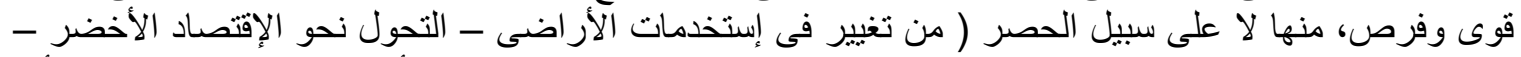

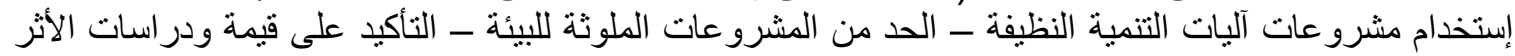
البيئى ). 7. على وز ارة الإعلام و المؤسسات الإعلامية بالدولة أن تنشر وتسعى لنشر والتوعية المجتمعية لمفهوم التكيف و التنمية المستدامة والتوجه نحو مشرو عالات التتمية النظيفة.

ا. . أحمد محمد عبدالهاه، سالم محمد عبداللاه، جامعة حضرموت ـ المكلا ـ اليمن، ندوة إدارة الكوارث وسلامة المباني في الدول العربية,

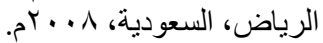

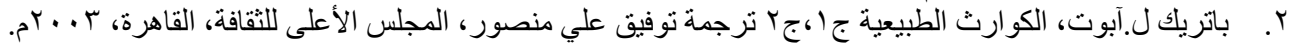

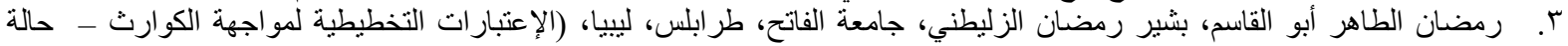

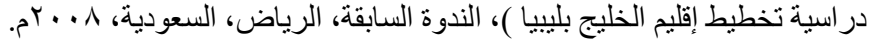




\section{دور التخطيط العمراني في مجابهة مخاطر غرق الدلتا جراء ظاهرة الإحتباس الحراري}

ع. عبد الفتاح البنا، شركاء التنمية للبحوث و الإستشار ات و التدريب، ( مواجهة آثار التغيرات المناخية المرتقبة على المدن التراثية الساحلية في

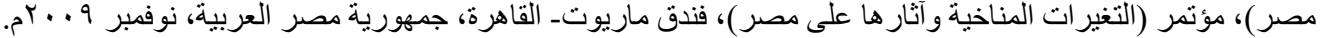

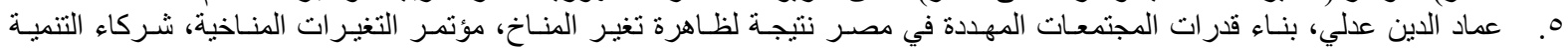

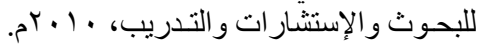

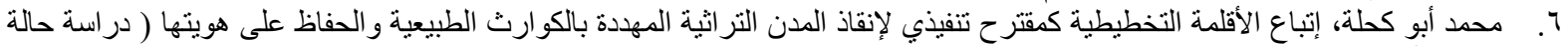

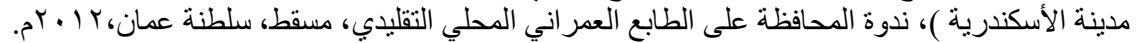

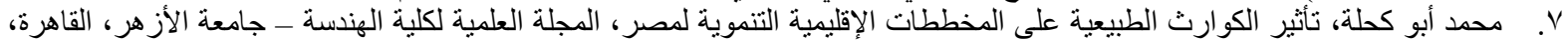

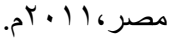

^. محمد أبو كحلة، دور التخطيط العمر انى فى مواجهة الكوارث الطبيعية المؤثرة على الهياكل العمر انية فى مصر، رسالة ماجيستير، القاهرة،

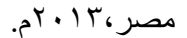

9 . محمد عبدالباقي إبراهيم، الحاجة إلى مدخل تنظيمى لمواجهة الكوارث الطبيعية، المؤتمر الدولى الأول عن " البيئة و التتمية في أفريقيا "،

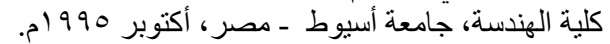

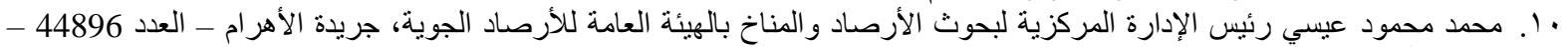

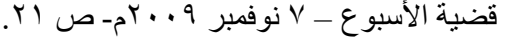

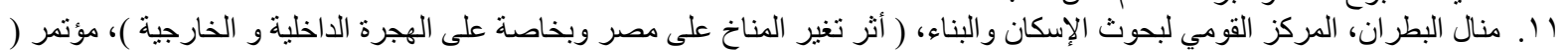

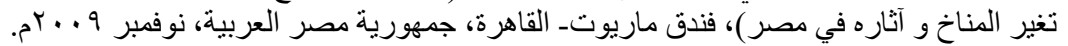

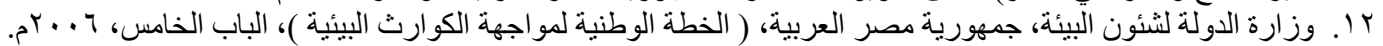

13. Hzami, A., Heggy, E., Amrouni, O., Mahé, G., Maanan, M., \& Abdeljaouad, S. (2021). Alarming coastal vulnerability of the deltaic and sandy beaches of North Africa. Scientific Reports, 11(1), 1-15.

14. https://globalsolaratlas.info/download/egypt

15. https://www.populationpyramid.net/carbon-emissions/china+united-states-of-america+russian-federation/

16. https://coastal.climatecentral.org/map/9/31.1322/30.9459/?theme=water_level\&map_type=water_level_above_ mhhw\&basemap=hybrid\&contiguous=true\&elevation_model=best_available\&refresh=true $\&$ water_level $=0.5 \&$ water_unit=m 